\title{
The 1968 andesitic lateral blast eruption at Arenal volcano, Costa Rica
}

\author{
Guillermo E. Alvarado ${ }^{a, *}$, Gerardo J. Soto ${ }^{a}$, Hans-Ulrich Schmincke ${ }^{b}$, \\ Louise L. Bolge ${ }^{\mathrm{c}}$, Mari Sumita ${ }^{\mathrm{b}}$ \\ a Observatorio Sismológico y Vulcanológico de Arenal y Miravalles (OSIVAM), Instituto Costarricense de Electricidad (ICE), \\ Apdo. 10032-1000, Costa Rica \\ ${ }^{\mathrm{b}}$ SFB 574, University of Kiel and Leibniz Institute for Marine Science (IFM-Geomar), Wischhofstrasse 1-3, 24148 Kiel, Germany \\ ${ }^{\mathrm{c}}$ Boston University, Department Earth Sciences, 685 Commonwealth Ave., Boston, MA 02215, USA
}

Received 6 June 2005; accepted 28 March 2006

\begin{abstract}
The magmatic andesitic eruption of Arenal volcano on July 29-31, 1968, after centuries of dormancy, produced three new fissural craters (A, B and C) on its western flank and a multilayered pyroclastic deposit emplaced by complex transport mechanisms. The explosions were initially triggered by a volatile oversaturated (4-7 wt.\% $\mathrm{H}_{2} \mathrm{O}$ ) magma. Several lines of evidences suggest a small blast surge, where a wood-rich pyroclastic deposit was emplaced as a ground layer, followed by several units of coarse-grained $\left(\mathrm{Md}_{\Phi}\right.$ between -0.65 and -5.40$)$ tephra deposits (LU: lapilli units, DAU: double ash units). LU-1, -2, -3, DAU-1 and -2 consist of unconsolidated and well- to poorly sorted vesiculated bombs and lapilli of andesite, some blocks, ash and shredded wood. The individual units are possibly correlated with the major explosions of July 29. The thickness of the deposits decreases with the distance from the volcano from $5.6 \mathrm{~m}$ to a few centimeters. On average, $90 \%$ of the components are juvenile (10\% dense andesite and $90 \%$ vesicular). These coarse-grained beds were deposited in rapid succession by a complex transport process, involving normal fallout, strong ballistic trajectories with a lateral hot $\left(\sim 400{ }^{\circ} \mathrm{C}\right)$ blast surge ( $\mathrm{LU}$, equivalent to $\mathrm{A}_{1}$ ). Ballistic and coarse tephra sprayed in a narrow $\left(85^{\circ}\right)$ area within about $5.5 \mathrm{~km}$ from the lowest crater, and a high $(\mathrm{ca} .10 \mathrm{~km})$ eruption column dispersed airfall fine lapilli-ash $>100 \mathrm{~km}$ from the volcano. Ashcloud forming explosions, producing thin pyroclastic surge and muddy phreatomagmatic fallout deposits (FLAU, equivalent to $A_{2}$ and $A_{3}$ ), closed the blast surge sequence. The successive explosions on July 30-31 mainly produced block and ash flows, and widely dispersed ash fall. The total volume of pyroclastic material is calculated as $25.8 \pm 5.5 \times 10^{6} \mathrm{~m}^{3}(9.4 \pm$ $2.0 \times 10^{6} \mathrm{~m}^{3}$ DRE). A model is proposed to explain the peculiarities of the formation, transportation and emplacement of the blast deposits. The intrusion of the presumed andesitic cryptodome possibly happened through an active thrust fault, favoring not only the formation of the lowest crater A, but also the low-angle explosive events. Prior to the eruption, several minerals were settling to the bottom of the magma chamber as is suggested by the increase of incompatible elements towards the bottom of the stratigraphic section. The major elements indicate that some crystal redistribution occurred and the maximum concentration of $\mathrm{Al}_{2} \mathrm{O}_{3}$, and $\mathrm{Eu}$, and $\mathrm{Sr}$ support plagioclase enrichment in early phases of the eruption (top of LU-1 and DAU-1). From the about 20 recognized prehistoric and historic blast deposits in the world, approximately half were produced by sector collapse of the volcano and the other half by sudden decompression of cryptodomes or lava-dome collapses. The recent blasts (1888-1990s) elsewhere have an apparent recurrence of one event/decade, compared to just a
\end{abstract}

\footnotetext{
* Corresponding author. Tel.: +506 2208217.

E-mail address: galvaradoi@ice.go.cr (G.E. Alvarado).
} 
dozen described for the previous $50 \mathrm{ka}$. Therefore, the adequate recognizers of the blast facies in the cone-building lithofacies, especially for small stratocones as described here, can help in understanding other historic and prehistoric cases, and their related hazards.

(C) 2006 Elsevier B.V. All rights reserved.

Keywords: Arenal; lateral blast; andesitic dormant volcano; sedimentological features; eruptive mechanisms; transport mechanisms; structural control

\section{Introduction}

Arenal $(1.1 \mathrm{~km}$ in height, $\sim 1720 \mathrm{~m}$ above sea level, $15 \mathrm{~km}^{3}$, Fig. 1), in Costa Rica, is one of the 16 most active volcanoes in the world (Simkin and Siebert, 2000). It has been notable for the production of pyroclastic flows since the volcano renewed its activity in 1968, following several centuries of dormancy (Melson and Sáenz, 1973; Borgia et al., 1988; Alvarado and Soto, 2002). The 1968 eruption and its disastrous effects are discussed in three widely quoted papers (Melson and Sáenz, 1968, 1973; Minakami et al., 1969), and typified in several textbooks as an Ultra-Vulcaniantype eruption (Williams and McBirney, 1979) or Vulcanian type (Sigurdsson et al., 2000; Schmincke, 2004). One of the notable aspects of this eruption was the bombardment by ballistic blocks, which estimated ejection angles varied between $45^{\circ}$ and $60^{\circ}$, resulting in some of the earliest quantitative papers on eruption velocities (Melson and Sáenz, 1968; Minakami et al., 1969; Fudali and Melson, 1972). Erupted blocks, originally calculated as being ejected at $220-250 \mathrm{~m} \mathrm{~s}^{-1}$ (Melson and Sáenz, 1968) and 180-200 $\mathrm{m} \mathrm{s}^{-1}$ (Minakami et al., 1969), and later recalculated as fast as $\sim 600 \mathrm{~m} \mathrm{~s}^{-1}$ (Fudali and Melson, 1972), are now thought to have been ejected at roughly $360-410 \mathrm{~m} \mathrm{~s}^{-1}$ (Steinberg and Lorenz, 1983). These and other previous studies focused on the description of the eruption (energy, velocity and volume), the destructive effects of "nuées ardentes" between July 29 and 31, 1968, and premonitory and subsequent seismic phenomena (Matumoto, 1976; Sáenz, 1977).

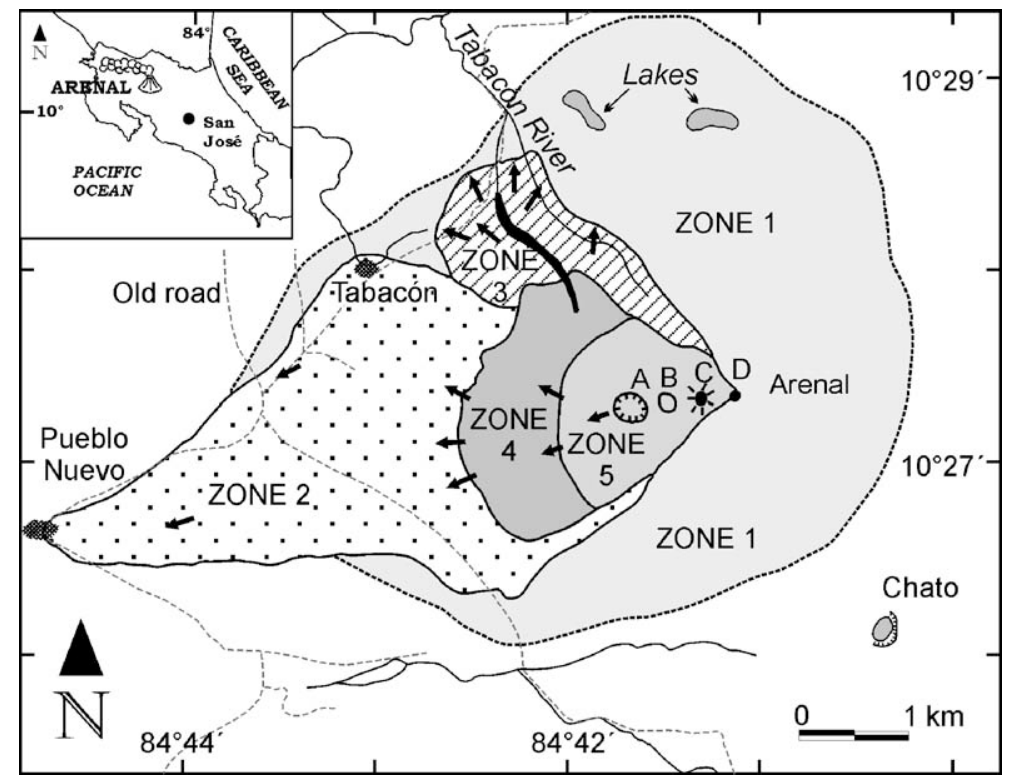

Fig. 1. Location map of Arenal volcano and zones devastated in 1968 (modified from Melson and Sáenz, 1968; Minakami et al., 1969; our work). Zone 1: The dashed line shows the limit of concentrated or isolated bombs, vegetation being uncharred. Zone 2: Region affected by explosions of July 29-30, with plentiful impact craters, seared or withered vegetation, and common uprooted trees. Most human fatalities occurred in this zone. Zone 3: Region affected by explosions of July 31. The narrow black area shows the block and ash flow deposit at Tabacón river. Zone 4: Area with few impact craters, the vegetation was completely destroyed and contained locally thick block and ash flow deposits. Zone 5: Innermost zone, with the three new craters, impact craters sparse and vegetation completely stripping. The arrows show the orientations of fallen trees based on 1968 photographs and data field in 2004. 
Although several abstracts have been presented in the last 12 years (Boudon et al., 1994, 1996; Villemant and Boudon, 1997; Alvarado et al., 1997, 2004), detailed descriptions and interpretations of the 1968 volcanic deposits are still lacking. The importance of understanding the generation and emplacement of pyroclastic density currents in the wide sense, and the hazard posed by the activity at Arenal volcano have led us to reexamine the 1968 deposits, much of which are already covered by more recent deposits. Based on a descriptive inventory and reconstruction of the events of the 3-day long eruption, we focused on several problems in this paper: chronology of the volcanic events, eruptive and transport mechanisms, and structural control, along with some petrochemical contributions. Better knowledge of these problems at Arenal could help to understand other proximal deposits of highly explosive volcanoes and, therefore, contribute to volcanic hazard assessments.

\subsection{Methods}

Field work included the measurement of detailed stratigraphic sections, internal structure, petrography, texture and grain size analyses, and mapping of the 1968 (and post-) deposits. Thirty-five stratigraphic sections of tephra deposits from the 1968 eruption were measured along radial traverses to the volcano, as well as other localities. Most of the detailed stratigraphic sites are on roads or in erosional channels, but several vertical- walled trenches (ca. $7 \mathrm{~m} \times 4 \mathrm{~m} \times 3 \mathrm{~m}$ ) were dug, exposing the entire deposits parallel to the axis of tephra dispersion. Unfortunately, about $5.6 \mathrm{~km}^{2}$ (>37\%) of the proximal tephra deposits are now covered by the recent (1968-2005) blocky lava flow fields, by the 1975 and 1993 pyroclastic flow deposits, by epiclastic deposits, or have been partially or completely eroded (Figs. 2 and 3).

Therefore, documents (papers in journals, internal reports, newspapers) and photographs of the zone affected on July 29-31 were meticulously reviewed and analyzed for understanding the deposits and transport mechanisms. The height of successive eruption columns can be estimated from photographs. Grainsize, density and proportion of different components, and then the volumetric calculation and counting of them, were performed in detail for 50 samples. Representative samples from the different types of deposits were selected for microscopic investigations. Major element oxides from large single juvenile clasts in stratigraphic position were measured by DCP-AES (directly coupled plasma atomic emissions spectrometer) at Rutgers University, New Jersey, USA. Trace element analyses were performed on a Finnigan MAT high resolution inductively coupled plasma mass spectrometer (HR-ICP-MS) at Institute of Marine and Coastal Sciences at Rutgers University. A lithium metaborate flux was used to digest samples for DCPAES analyses and $\mathrm{HF} / \mathrm{NHO}_{3}$ digestion was utilized for

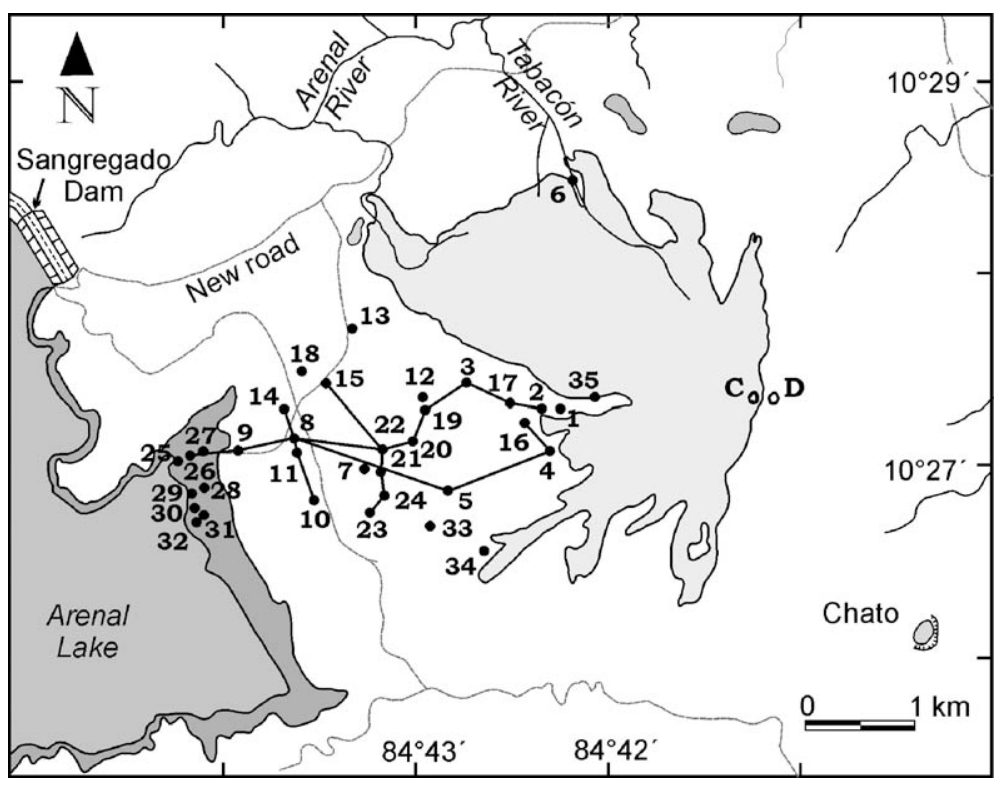

Fig. 2. Location map of stratigraphic sections of 1968 eruption and lava field (1968-2005, light gray). The innermost line into the Arenal lake (a manmade reservoir since 1978) shows the lowest water level of the lake, in January 1994. 


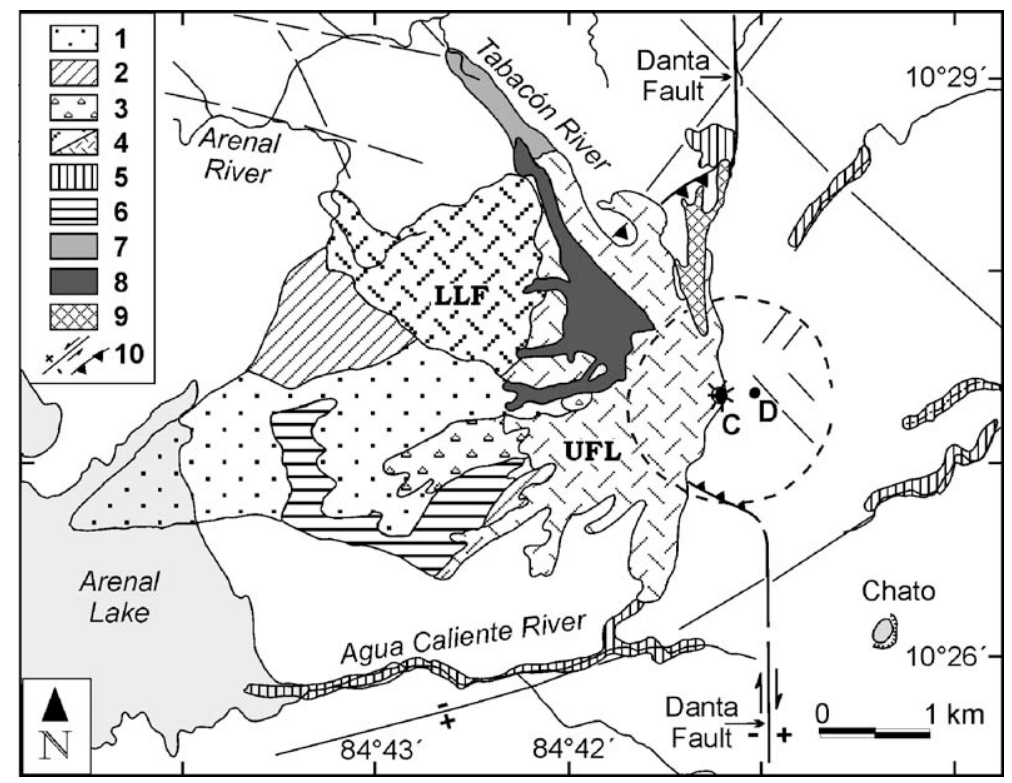

Fig. 3. Geologic map of Arenal volcano showing units from 1968 to 2005: (1) thick 1968 tephra; (2) hummocky morphology produced by 1968 impact craters (heavy ballistic deposits); (3) 1968 block and ash flow deposits; (4) recent lava flows; LLF: Lower Lava Field erupted between September 1968 and 1973, ULF: Upper Lava Field erupted since 1974 up to 2005; (5) volcaniclastic material eroded mainly from the lava fields; (6) epiclastic fans composed by deposits of reworked 1968 tephra; (7) June 1975 pyroclastic flow deposits; (8) August 1993 pyroclastic flow deposits; (9) 2000, 2001 and 2003 pyroclastic flow deposits. The dashed line shows the limit of bombarding by Strombolian activity from 1984 to 2005; (10) faults and their movement.

HR-ICP-MS analyses (see Feigenson and Carr, 1985; Feigenson et al., 2003, for the detailed methods).

\section{Narrative of the July $29-31,1968$ eruption}

Seismic phenomena at Arenal started as early as 1963, as isolated earthquake swarms (Fig. 4). Between 1951 and 1965, impending volcanic activity was heralded by: (a) colorless gas ( $\mathrm{CO}$ and/or $\mathrm{CO}_{2}$ ?) emissions on the NE flank of the volcano, affecting animals and vegetation; (b) water level of Cedeño lake on the north flank dropping completely, causing fish death; (c) hot springs increasing their discharge temperature in 1967 at Tabacón river (which drains the volcano on the northwest); (d) fumaroles at the summit crater increased in number: 8 in 1937, 15 in 1951 and 30 in 1959; (e) Platanillo creek waters, on the northeast flank, changed their taste; and (f) cows were seen by farmers moving down from the middle upper slopes of the volcano 2 weeks prior to the initial eruption (Bolt et al., 1975; Barquero et al., 1992; Molina, 2003). On July 28 1968, beginning at approximately 2300 LT (local time: LT=GMT-6 h), the inhabitants of Tabacón and Pueblo Nuevo villages (now covered by recent lava flows and by the Arenal lake, respectively; Figs. 1-3) at the western foot of the volcano, reported numerous earthquakes, which increased in intensity and number with time. The earthquake swarm decreased less than $2 \mathrm{~h}$ before the initial paroxysmal explosion, with the highest magnitude estimated at 4.5 (Matumoto, 1976). Later calculations by Zobin (2001) showed $M_{\max } 5.1$.

The first of a series of large explosions began at 0730 on July 29. Three explosion craters aligned roughly east-west (A, B and C, Fig. 1) were formed. It is not clear, however, if the three new craters opened simultaneously or sequentially. About 70 people died in the villages of Tabacón and Pueblo Nuevo, principally by burns from hot gases and tephra and injuries from ballistic blocks. Additional explosions occurred at 1000, 1130, and also probably at 1400 and 1510 , and lasted with ebbs and maxima through July 30 $(0500,1100)$. The last fatalities (8 people) occurred around 1310 on July 31, when a major explosion occurred, and a hot ash-cloud surge (associated with a block and ash flow) overwhelmed two rescuing cars near the Tabacón river (Melson and Sáenz, 1968; Minakami et al., 1969; Sáenz, 1977). The height of successive eruption columns on July 30 (i.e., 0500, $1100,0130)$ were estimated by airplane pilots, ranging between 6.5 and $10 \mathrm{~km}$.

The largest explosion crater A $(250 \mathrm{~m}$ across, $7 \pm$ $\left.2 \times 10^{6} \mathrm{~m}^{3}\right)$ at the lowest elevation $(\sim 1060 \mathrm{~m})$ was 
(a)

Increasing $T$ at Tabacón hot spring

Cedeño Lake dried

Moffetes

Earthquakes

Summit fumarolic activity

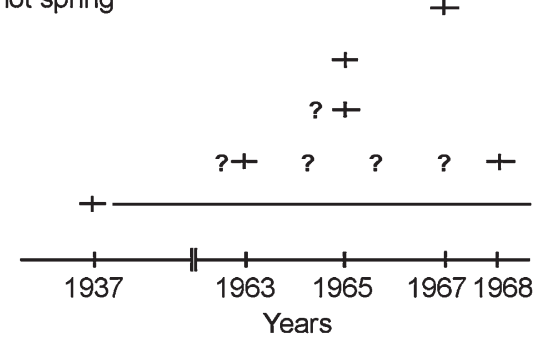

(b)

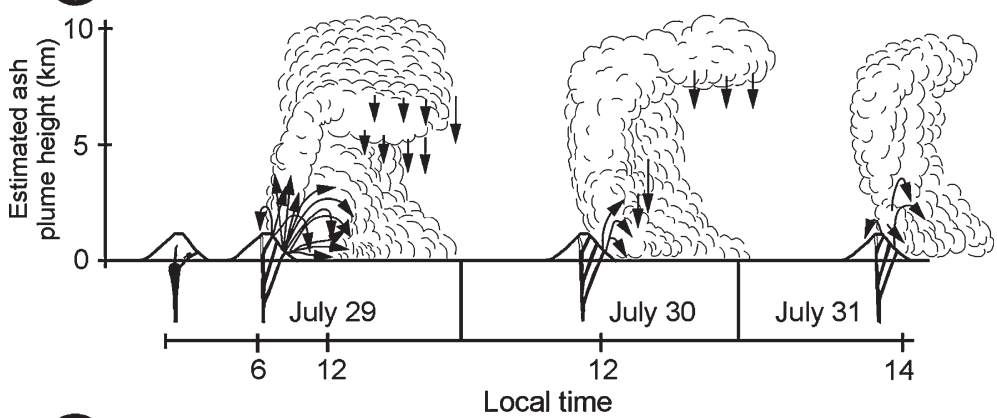

()

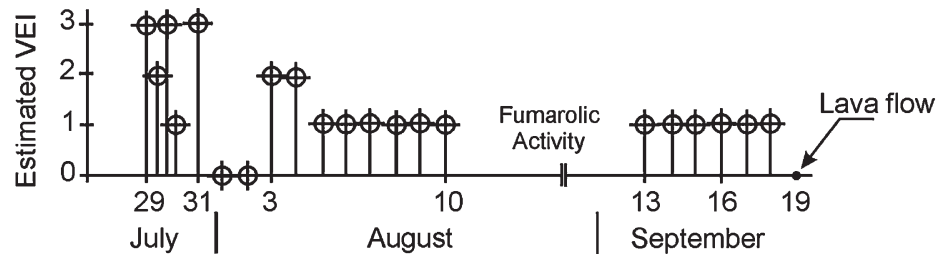

Fig. 4. Premonitory and related phenomena associated with 1968 Arenal eruption. (a) Events prior to 1968. (b) Cartoon showing main volcanic activity previous and during the paroxysmal phases on July 29-31, 1968. (c) Eruptive phases and maximum volcanic explosivity index (VEI) of early events in 1968 eruption.

rimmed by coarse tephra deposits and locally by large angular blocks up to $50 \mathrm{~m}$ in diameter. Craters B $(\sim 1160 \mathrm{~m})$ and $\mathrm{C}(\sim 1400 \mathrm{~m})$ were smaller than $\mathrm{A}$; crater D $(1633 \mathrm{~m})$ was pre-existing but not active at the time of the eruption. A digital topographic map made after detailed analyses of aerial photographs taken in 1961 shows a possible previous crater-like structure in the same location where the crater A opened (S. Chiesa, oral comm., 1995). Vegetation was completely destroyed and removed close to the explosion craters, but seared or withered vegetation and uprooted trees were common in buried areas up to $3 \mathrm{~km}$ downhill from crater $\mathrm{C}$. Throughout this area, trees were blown down, topped or scorched. Orientations of fallen trees (Fig. 1), directions of long axes of impact craters and the radial distribution of block-and-ash flows around the lowest crater showed quite clearly that most, if not all, of the devastating explosions of July 29-31 originated from crater A (Melson and Sáenz, 1968).
At Pueblo Nuevo village, many houses remained standing, but were partially or totally destroyed principally by the ballistic impacts of bombs and/or collapse by ash accumulation on roofs. Near Pueblo Nuevo, the trees were standing with branches intact, but leaves completely stripped.

Melson and Sáenz $(1968,1973)$ and Minakami et al. (1969) found that some of the wooden houses at Pueblo Nuevo were charred by the tephra. They estimated the temperature of fine ejecta and air in the range of 300 to $500{ }^{\circ} \mathrm{C}$. Several trees and plastics objects, glass bottles, etc. were burned and/or molten, suggesting a temperature between 600 and $800{ }^{\circ} \mathrm{C}$, possibly because they were in direct contact with bombs (Sáenz, 1977).

The strong explosive phase was followed by a small amount of ash ejected between August 1 and approximately August 10. Fumarolic emission continued to decline between August 10 and September 13. Eruptions resumed at about 1540 on September 13 and 
Table 1

Average volume percentage of components for each lapilli unit, and their corresponding range and average density

\begin{tabular}{|c|c|c|c|c|c|c|c|}
\hline Components & LU-1 & DAU-1 & LU-2 & DAU-2 & LU-3 & $\begin{array}{l}\Delta \text { range } \\
\left(\mathrm{g} \mathrm{cm}^{-3}\right)\end{array}$ & $\begin{array}{l}\text { Average } \Delta \\
\left(\mathrm{g} \mathrm{cm}^{-3}\right)\end{array}$ \\
\hline Vesiculated juvenile clasts & 63 & 55 & 58 & 32 & 45 & $1.35-1.66$ & 1.47 \\
\hline Dense juvenile & 4 & 3 & 4 & 12 & 4 & $2.20-2.65$ & 2.43 \\
\hline Hydrothermally altered lithics & 2 & $<1$ & 2 & $<1$ & 2 & $2.34-2.52$ & 2.46 \\
\hline Fresh accidental lithics & 2 & 1 & 5 & $<1$ & 2 & $2.58-2.81$ & 2.69 \\
\hline Matrix (ash to fine lapilli size, bulk) & 29 & 41 & 31 & 56 & 47 & - & 1.50 \\
\hline Total & 100 & 100 & 100 & 100 & 100 & - & - \\
\hline
\end{tabular}

another strong explosive phase began at 2149 on September 16, lasting through September 18. A basaltic andesite blocky lava flow started to be extruded from crater A on September 19 (Melson and Sáenz, 1968; Sáenz, 1977; this work).

The explosions on July 29 and 31 devastated $13.3 \mathrm{~km}^{2}$ and $3 \mathrm{~km}^{2}$, respectively, for a total area (overlapping) of about $15 \mathrm{~km}^{2}$; the area slightly affected by ash was $230 \mathrm{~km}^{2}$ and traces of ash covered $1580 \mathrm{~km}^{2}$ (Chaves and Sáenz, 1970; Sáenz, 1977).

\section{Components and stratigraphy of the deposits}

Based on the works of Melson and Sáenz (1968), Chaves and Sáenz (1970), Sáenz (1977) and our field work, we defined, for the 1968 tephra deposits, a proximal facies $(0-2.5 \mathrm{~km}$ western from the lowest crater A: limit of the block and ash flows), a medium facies $(2.5-5.5 \mathrm{~km}$ : limit of the devastated area from the lowest crater and just the maximum distance for ballistic bombs) and a distal facies ( $>5.5 \mathrm{~km}$ : mainly fallout ash). Our study is concentrated on the proximal-medium facies.

The deposits are composed of three main components (Table 1): (1) juvenile gray vesicular bomb to ash-sized particles. The bomb interiors are gray to pink; densities are 1.35 to $1.66 \mathrm{~g} \mathrm{~cm}^{-3}$ and vesicles $(<0.5 \mathrm{~cm}$ in diameter) range from $38 \%$ to $50 \%$. (2) Dense juvenile clasts (vesicularity between $2 \%$ and $19 \%$ ), including nonvesicular, black glassy blocks (vitreous luster on fresh surfaces), lapilli with open joint cracks and some breadcrusted blocks. More than $90 \%$ of the clasts are of the same juvenile magma type and, therefore, the deposits are almost monolithologic (Table 2). (3) Accidental clasts include blocks, lapilli and ash of older fresh basaltic

Table 2

Percentage of juvenile and non-juvenile components of the lapilli units

\begin{tabular}{lcclcc}
\hline Components & LU-1 & DAU-1 & LU-2 & DAU-2 & LU-3 \\
\hline Non-juvenile clasts & 6 & 2 & 10 & 1 & 8 \\
Juvenile clasts & 94 & 98 & 90 & 99 & 92 \\
\hline
\end{tabular}

andesite lavas with minor oxidized surfaces (fresh accidental lithics), volcanic breccias from the crater and conduit walls, and yellow to orange-red hydrothermally altered lithics, presumably representing vent-wall materials that were ejected during the eruption; gabbro fragments are very rare. The term "matrix" (as a field criterion) hereafter refers to ash and fine lapilli $<4 \mathrm{~mm}$.

From field characteristics, the deposits can be referred to four main lithofacies and corresponding emplacement mechanisms, as follows (Fig. 5).

\subsection{Basal layer $(B L)$}

Basal layer was examined in two trenches (\#17 and 19, Figs. 2, 5 and 6), located about 1 and $2.5 \mathrm{~km}$, respectively, westward from the lowest crater, and in some isolated outcrops, where the overlain tephra sequence is now deeply eroded. This layer consists of two parts: (a) A basal light-colored layer $(4-12 \mathrm{~cm}$ thick) overlies a humic soil, which is darker towards the top. The poorly bedded layer is composed of very fine ash and fine gray-white andesitic pumiceous lapilli, rounded to subrounded (up to about $2 \mathrm{~cm}$ in diameter but mostly $<0.5 \mathrm{~cm}$ ). (b) An upper massive light colored tephra layer, rich in wood fragments, generally about $20-30 \mathrm{~cm}$ thick but locally thickens to $70 \mathrm{~cm}$, and shows dune-like structures. It is composed of $>50 \%$ coarse ash, the remainder being organic material, mostly branches and small twigs, many of them coated with the light-colored ash. Elongated branch fragments appear to be roughly aligned down slope the cone. Some large wood fragments $(1-7 \mathrm{~m}$ long and $>10 \mathrm{~cm}$ across $)$ and most of the small ones ( $<10 \mathrm{~cm}$ long and $<2 \mathrm{~cm}$ thick) are black charcoal, though some are only marginally carbonized.

\subsection{Lapilli units (LU) and double ash units (DAU)}

The upper part of the basal layers is separated by a very sharp boundary from the overlying lapilli units (LU), which consist of five coarse-grained layers (called 
WEST

EAST

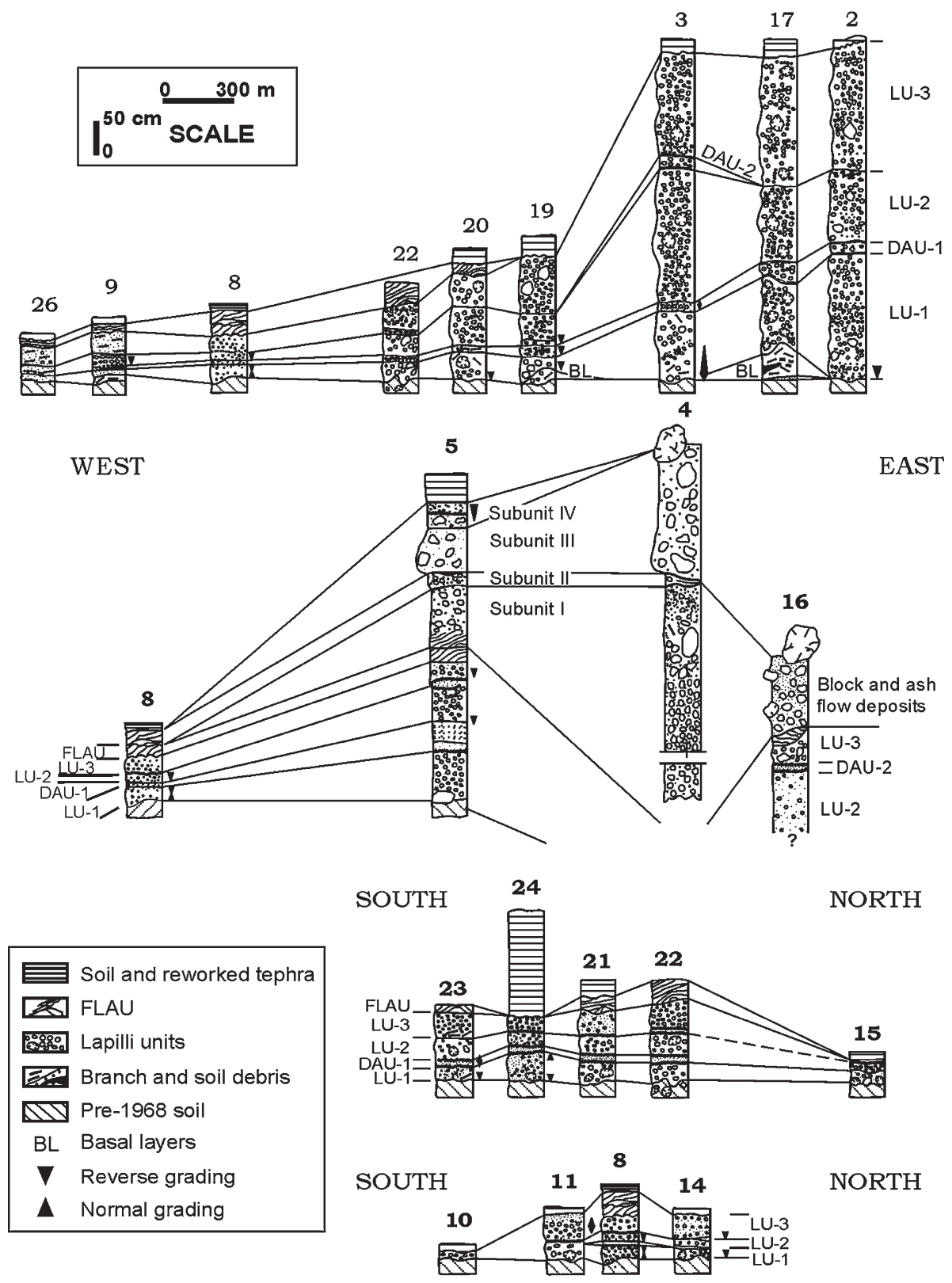

Fig. 5. Stratigraphic correlation of main measured sections. Numbers of localities in Fig. 2.

LU-1 to -3 and DAU-1 and -2) with a maximum observed total thickness of $5.6 \mathrm{~m}(1 \mathrm{~km}$ from the lowest crater A; presumable thicker toward the crater). The layers are poorly stratified, friable, openwork texture and paucity in fines (Fig. 6). They are composed of 1578 vol.\% gray to pink bombs and moderately vesicular lapilli, 0-9 vol.\% hydrothermally altered blocks and lapilli, 0-21 vol.\% juvenile breadcrusted or angular blocks/lapilli, and 0-14 vol.\% non-juvenile unaltered blocks and lapilli. Matrix varies between 8 and 64 vol.\%.
Carbonized wood, including fallen tree trunks, is moderately abundant.

In general, ballistic fragments are present elsewhere in the LU. Very rare bombs were plastically deformed. Impact craters formed mainly on the western flank of the volcano, but also occur in several other places around the volcano as isolated craters (Fig. 1). Most impact craters range in diameter between $<1 \mathrm{~m}$ and $8 \mathrm{~m}$, despite the largest measured $60 \mathrm{~m}$ across and $4 \mathrm{~m}$ in depth. Large impact craters were devoid of large fragments 

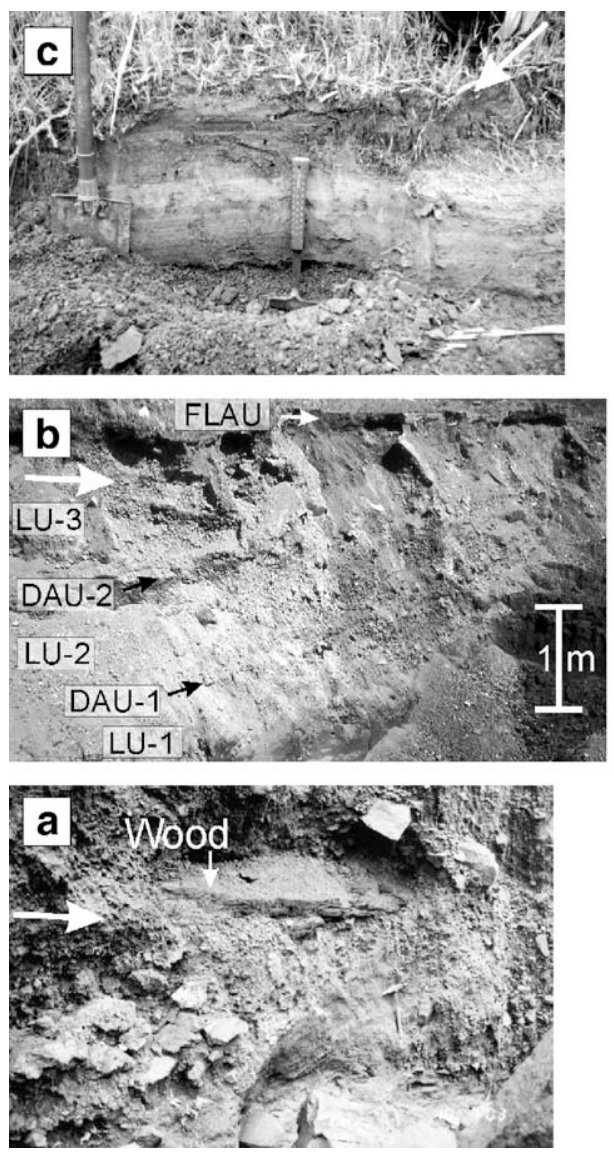
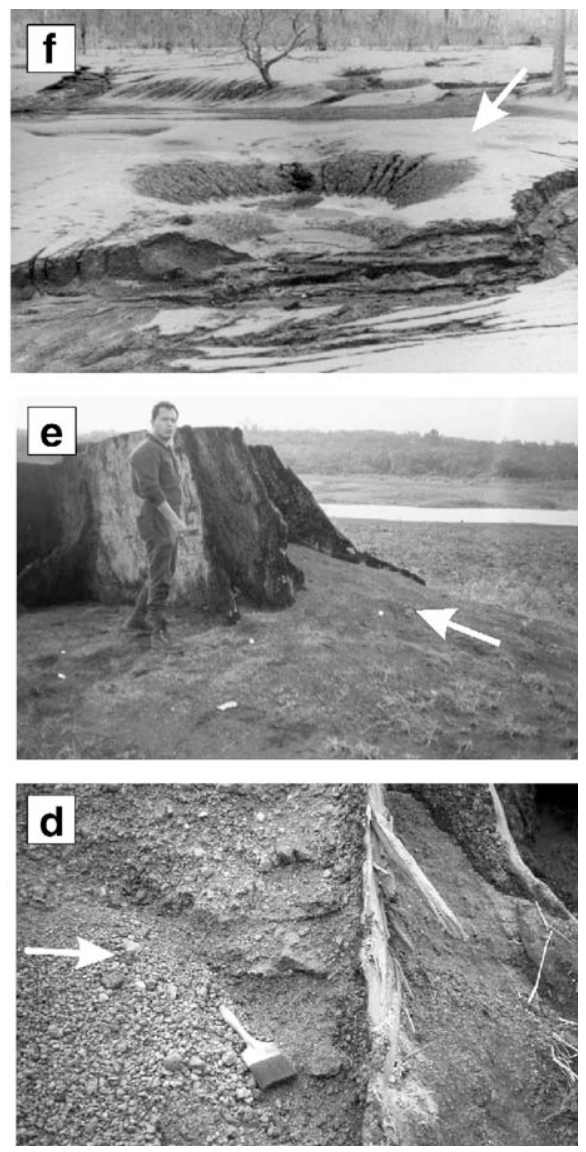

Fig. 6. (a) The Basal Layer (BL) with a large piece of partially burned wood (pickhammer for scale). (b) The whole LU, DAU and FLAU in the median facies. (c) Fine lapilli and ash unit (FLAU) overlying LU-3. It consists of several finely laminated ash and fines-armored-lapilli beds, with pinch-and-swell structures, accretionary lapilli in the lower part and a vesiculated tuff in the upper part. (d) Detail of LU in the proximal facies, with dominating diffuse lensoid layers (cross-like stratification) where well-sorted lapilli layers alternate with thick layers containing some coarse ash, and the open-frame structures. The LU is coarser upstream (left) than downstream (right) of the tree. (e) A dune structure deposited against a large partially, still-standing, burned tree in the distal facies at locality 26. Since 1978 has been below the Arenal Lake level and was ephemerally exposed in January 1994. (f) Large impact craters covered by the FLAU in the distal median parts, near Pueblo Nuevo (courtesy of A. López, ICE). The large white arrows show the direction of the blasts and bombardment in all pictures.

because projectiles disintegrated on impact; largely intact blocks were only found in craters $<2 \mathrm{~m}$ in diameter $>5 \mathrm{~km}$ from the vent. The number of craters per unit surface area (crater density) ranged widely in the devastated zone. The area near Tabacón was repeatedly covered by impacts, with overlapping craters, but impact density gradually decreased away from the lowest crater (Melson and Sáenz, 1968, 1973). It is still possible to recognize a hummocky morphology produced by the heavy rain of meter to decameter-sized bombs and blocks beneath the northwestern part of the younger (1975-2005) pyroclastic fan, along with very thin remains of the lapilli units (Fig. 3). In this area, isolated blocks (mostly juvenile) and swarms of blocks can still be identified in the internal part of the impact craters. In a trench at site 18 (Fig. 2) and in natural outcrops (e.g.,
8 and 12), it is possible to see how the pre-1968 tephra and/or epiclastic deposits, and rare anthropogenic material (some shards of porcelain and glass fragments), were ejected because the impacts and then deposited as a mixture (up to $1 \mathrm{~m}$ thick in localities 12 and 18). Soil is partially missing in places where the ballistic projectiles hit the ground (e.g., 3 and 8), or bombs and lapilli are mixed or incrusted several centimeters into the pre-1968 soil layer (15 and 22, Fig. 5).

\subsubsection{Lapilli Unit 1 (LU-1)}

LU-1 is the lowermost of the lapilli units and is generally inversely graded. It largely consists of moderately to well-sorted dense gray lapilli and bombs, some $>0.5 \mathrm{~m}$ across in the proximal facies, floating in a more or less non-cohesive ash- and lapilli-matrix, with 
diffuse pinch-and-swell structures. The content of juvenile fragments increases with distance from the source. Many bombs are located at the base, but some also at the top. Some are associated with strongly carbonized wood, these bombs having a dark silvery glossy sheen, due to carbon-coating in a reducing environment. Wood debris, generally not carbonized, occurs concentrated principally in the upper parts of the unit. The thickness of LU-1 decreases from about $1.5 \mathrm{~m}$ in the proximal facies to $<10 \mathrm{~cm}$ in the medium facies of the tephra fan, about $2.5 \mathrm{~km}$ downslope (Fig. 5).

\subsubsection{Double Ash Unit 1 (DAU-1)}

LU-1 is followed by the 5-30 cm DAU-1 deposit that begins relatively abruptly with a $4 \mathrm{~cm}$ thick reversely graded ash, irregularly distributed, followed by a coarser-grained thick central part $(20 \mathrm{~cm})$, and a layer rich in brown ash $5 \mathrm{~cm}$ thick in the upper part. The fine ash at the bottom and at top provided the local field name: double ash, because its texture was easy to recognize in the field. The coarse ash and lapilli are coated by fine ash. With overlying protruding bombs, this unit shows variations in bed thickness and a lack of mantle bedding. Locally, there occur elongated wood fragments that are roughly parallel to the overall bedding.

\subsubsection{Lapilli Unit 2 (LU-2)}

LU-2 is predominantly poorly to well-sorted and consists of a basal layer of bombs (some fragments are contained in impact sags), dense juveniles (average 4 vol.\%, with a decrease in content with distance) and matrix (14-49 vol.\%; average $31 \mathrm{vol} . \%$, a little finer than in LU-1), generally with mantle bedding, coarsening upwards. This horizon is overlain by a bomb-rich deposit supported by grain-to-grain contact, reversely graded in some cases, commonly with lenticular bedding, ash and fine lapilli layers, rare non-juvenile blocks, and diffuse cross-bedding. Around $50-80 \%$ of the lapilli are more angular than those in LU-1, while LU-2 is coarsergrained and more poorly sorted than LU-1, because of slightly brownish fine-grained ash coating many lapilli. The thickness of LU-2 decreases from $1.2 \mathrm{~m}$ in the proximal area to $<20 \mathrm{~cm}$ in the medium facies. Organic matter and soil inclusions or local sublayers instead of DAU are common in medium facies deposits between LU-1 and LU-2 (Fig. 5).

\subsubsection{Double Ash Unit 2 (DAU-2)}

DAU-2 usually consists of an ash coated lapilli deposit up to $25 \mathrm{~cm}$ thick that begins relatively abruptly with $4 \mathrm{~cm}$ of fine, discontinuously, normally graded ash, followed by coarser-grained lapilli and ash, and a layer rich in brown ash in the upper part. LU-2 is locally overlain by a fine- to medium-grained gray ash deposit, with some rare lapilli and carbonized wood. Also, locally, parts of this unit are vesiculated tuffs (cf. Lorenz, 1974) and coated lapilli. There is as well mixing of soil and tephra and some elongated wood fragments orientated largely parallel to bedding.

\subsubsection{Lapilli Unit 3 (LU-3)}

The uppermost lapilli unit is about twice the thickness of the lower two lapilli units: a minimum of $2.15 \mathrm{~m}$ in the proximal facies to $<20 \mathrm{~cm}$ distally. It consists of $15-68$ vol.\% lapilli and bombs mixed with some dense juvenile lapilli and blocks (1-12 vol.\% quickly decreasing in content from proximal to medium facies; average 4 vol.\%), in grain to grain contact, followed by friable horizons in which bombs are concentrated, containing scattered fresh accidental blocks (1-8 vol.\%) and some core lava bombs. In the proximal facies, all levels have dominating diffuse lensoid layers about 2-20 cm thick where well-sorted lapilli layers alternate with $1-4 \mathrm{~cm}$ thick layers containing some coarse ash (Fig. 5). In the most distal part of the tephra fan (medium facies), the unit consists of several diffuse layers of coarse and fine ash (Fig. 5). The unit is locally normally graded at the top but often non-graded. The average grain size is smaller and in a narrower range than in LU-1 and -2, but there are some large blocks and bombs $>40 \mathrm{~cm}$ in diameter.

\subsection{Fine lapilli and ash unit (FLAU)}

In several localities (e.g., 5, 20 to 23, 25, 26 and 33, Fig. 5) a varicolored (gray, yellow, brown, green and orange) bedded fine lapilli to dominantly ash that conformably to unconformably overlies LU-3, about $15-20 \mathrm{~cm}$ thick, is found in small channels about $1 \mathrm{~m}$ wide and up to $25 \mathrm{~cm}$ deep (Fig. 6). It consists of several finely laminated ash and fines-armored-lapilli beds, inversely and normally graded, with pinch-and-swell structures and accretionary lapilli in the lower part, and a vesiculated tuff in the upper part (Fig. 5). At sites where the subsequent block and ash flow units were not deposited, their associated ash-cloud surges extended farther and deposited cross-stratified ash on top of the FLAU. The relationship is observed at locality 8 , where the FLAU is overlain by crosslaminated gray ashes (see Fig. 5).

\subsection{Block and ash flow deposits}

The block and ash flows reached their greatest thickness $(30 \mathrm{~m})$ at Tabacón river, though typically are 
around $10 \mathrm{~m}$, and they extend $2.2 \mathrm{~km}$ from the lowest crater A. One of the most voluminous block and ash flows partially filled the valley of Tabacón river, but is now covered by a post-1968 lava flow and pyroclastic flow sequences. Individual blocks measured 10-15 m across (Melson and Sáenz, 1968). More than 50 vol.\% of the clasts in the flow deposit are large (several meters across) juvenile clasts with cooling joints, striated surfaces, conchoidal fracture and a variable amount of vesicles (2-10 vol.\%), in clast-to-clast contact, in a poorly sorted matrix of ash, lapilli and blocks. The vesicular clasts abundant in the LU are absent in these block-rich deposits. Bomb-like components are characteristically rounded, slightly scoriaceous and represent a minor percentage of the flow deposit. All deposits contain carbonized wood fragments. The only outcrops still accessible (e.g., 4, 5 and 16, Figs. 2, 3 and 5) are on the western flank of Arenal, where at least three or four block and ash flow deposits (subunits I to IV) overlie LU and FLAU. The four subunits are:

Subunit I This is a $4 \mathrm{~m}$ thick (exemplified in section 4, Fig. 5), poorly sorted, noncohesive, which is characterized by the presence of juvenile and non-juvenile angular to subangular blocks. It varies from clast- to ash matrix-supported. Locally, in the lower part, there is a fine-grained gray ash deposit (up to $25 \mathrm{~cm}$ ), parallel-laminated to low-angle cross-laminated, with some small lapilli and carbonized wood debris.

Subunit II A lapilli layer in clast-to-clast contact with ash, and containing rare oriented and carbonized wood fragments, is enclosed in the middle of a thin (up to $6 \mathrm{~cm}$ ) gray to green fine ash and lapilli deposit, sometimes in small lenses. The maximum thickness is $22 \mathrm{~cm}$.

Subunit III It is a prominent gray to brown bed distinguished by its unusual cohesive appearance. The deposit is very poorly sorted and contains abundant decimetric to metric juvenile and accidental blocks and lapilli within an abundant gray ash matrix with some carbonized wood debris. The deposit has a longitudinally lenticular shape with a maximum thickness of $2 \mathrm{~m}$.

Subunit IV It is a local deposit observed only at locality 5. It consists of largely unstratified and hardened lapilli and ash deposit with the larger fragments in clast-to-clast contact.

\subsection{Reworked deposits}

Numerous small debris flows were produced during the eruption, principally along the Tabacón valley. Typically, the deposits consist of poorly sorted, angular to subrounded blocks in a matrix of lapilli and ash. They contained much charred and/or splintered wood (Melson and Sáenz, 1968). Additionally, since 1968, primary tephra deposits on the western flank have been modified by post-depositional erosion (and locally totally removed) and re-deposited as mass flows (normal streamflow to debris-flow deposits) up to $5 \mathrm{~m}$ thick. Other reworked deposits consist of lenticular matrix-poor beds, clast-supported, granule- to pebble-sized (dense and vesiculated volcanic fragments), reversely graded and were typically emplaced by grain flows. They form the modern fan shaped deposits on the slope (unit 6 in Fig. 3).

\section{Grain size distribution}

The pyroclastic deposits of the 1968 eruption widely vary in grain size. Although clasts $>8 \mathrm{~cm}$ are not included in the analyses, some conclusions can be obtained. All samples from the LU are coarse-grained and well to poorly sorted $\left(\sigma_{\varphi}=1-2.65\right.$, Table 3$)$. LU$1,-2$ and -3 are poor in ash content, and DAU-1 and -2 are moderately rich in ash. Because we have a few samples from DAU-1 and -2, they were lumped together in Table 3.

In general, in all units of the LU, median grain size decreases with distance from crater A. Fig. 7 illustrates this for units LU-1 and LU-2. At a distance between 1.8 and $2.4 \mathrm{~km}$ from crater $\mathrm{A}$, however, median size increases and sorting becomes better (Fig. 7). Beyond

Table 3

Grain size parameters for lapilli units

\begin{tabular}{|c|c|c|c|c|c|}
\hline Unit & $\sigma_{\varphi}$ range & $\begin{array}{l}\text { Average } \\
\sigma_{\varphi}\end{array}$ & Sorting & $\begin{array}{l}\mathrm{Md}_{\varphi} \\
\text { range }\end{array}$ & $\begin{array}{l}\text { Average } \\
\operatorname{Md}_{\varphi}\end{array}$ \\
\hline LU-1 & $1.08-2.10$ & 1.54 & Well-poorly & $\begin{array}{l}-0.65 \text { to } \\
-5.40\end{array}$ & -3.14 \\
\hline DAU-1/2 & $1.15-2.30$ & 1.58 & Well-poorly & $\begin{array}{l}-2.00 \text { to } \\
-4.50\end{array}$ & -3.08 \\
\hline LU-2 & $1.00-2.08$ & 1.42 & Well-poorly & $\begin{array}{l}-1.90 \text { to } \\
-4.45\end{array}$ & -3.07 \\
\hline LU-3 & $1.25-2.65$ & 1.61 & Well-poorly & $\begin{array}{l}-2.40 \text { to } \\
-3.50\end{array}$ & -2.90 \\
\hline
\end{tabular}




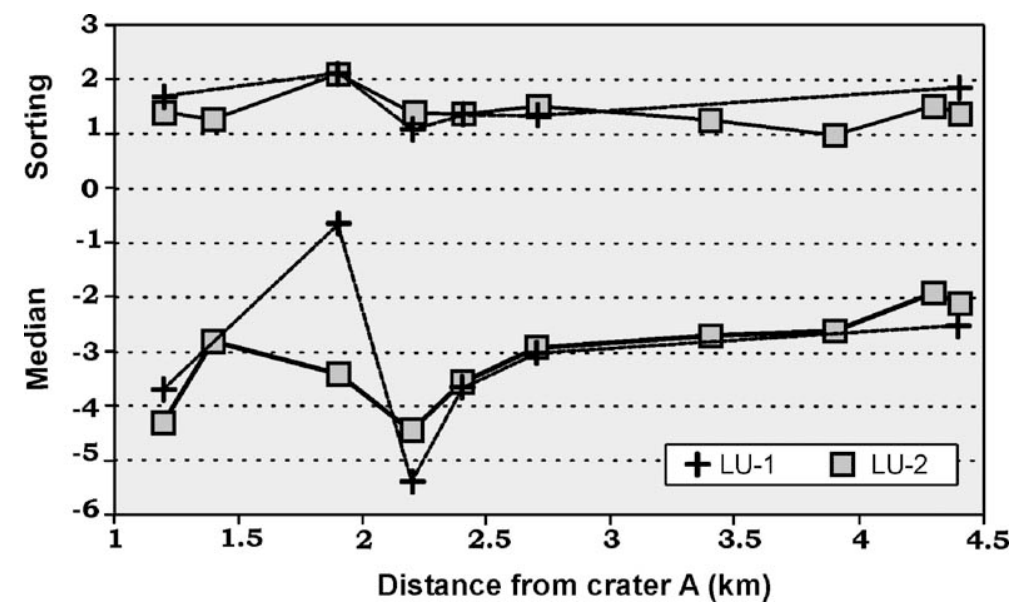

Fig. 7. Median $\left(\mathrm{Md}_{\Phi}\right)$ and sorting $\left(\sigma_{\Phi}\right)$ versus distance from crater A.

that distance, it seems that sorting becomes slightly worse in LU-1 and better in LU-2.

\section{Thickness variation and volume of the tephra deposits}

There have been no previous detailed studies of the tephra deposits of the 1968 eruption in order of isopach maps or sedimentological descriptions. The proximal tephra deposits were rapidly channelled by erosion, while more distal ash was removed by runoff and mass wasting processes. Natural and artificial outcrops are sufficiently well distributed, however, allowing nearvent isopach maps to be drawn (Fig. 8). Isopleth maps were not made because there is a mixture of ballistic dense blocks, broken bombs and lapilli of different densities.

The total volume of the pyroclastic material erupted was calculated as $43 \pm 21 \times 10^{6} \mathrm{~m}^{3}$ by Melson and Sáenz (1973) and $19.3 \times 10^{6} \mathrm{~m}^{3}$ by Sáenz (1977). In these papers, however, there are some doubts of how the fine airfall ash and the tephra from the proximal area have been estimated, because there are severe contradictions between the written texts and the tables. Using our new thickness measurements and isopach maps (Fig. 8), we extrapolated the curves based on our own observations and the maps from the above cited two papers, to calculate the volumes (Table 4). The thickness distribution of all LU shows an irregular fan downslope with an apex at the lowest crater $\mathrm{A}$ and a minor lobe directed to
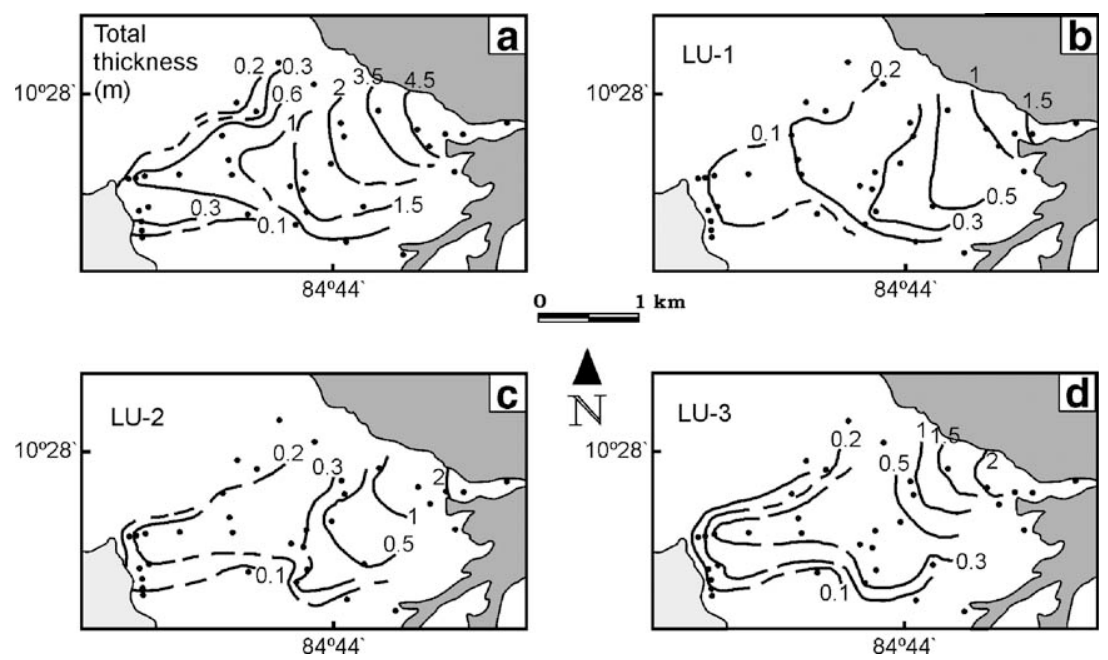

Fig. 8. Isopach map (in m) of the lapilli units. (a) Total thickness including DAU. (b) Lapilli Unit 1. (c) Lapilli Unit 2. (d) Lapilli Unit 3. In dark gray, the present lava field (1968-2005) and, in light gray, the Arenal lake. 
Table 4

Tephra volumes of the 1968 Arenal's eruption products

\begin{tabular}{lr}
\hline Unit & $\begin{array}{r}\text { Volume } \\
\left(10^{6} \mathrm{~m}^{3}\right)\end{array}$ \\
\hline LU-1 & $5.3 \pm 1.1$ \\
LU-2 & $5.9 \pm 1.2$ \\
LU-3 & $6.6 \pm 1.3$ \\
DAU and FU & $3.2 \pm 0.4$ \\
Block and ash flows ${ }^{\mathrm{a}}$ & $1.8 \pm 0.5$ \\
Fine airfall ash & \\
Whole pyroclastic deposits & $3.0 \pm 1.0$ \\
\hline${ }^{\mathrm{a}}$ Melson and Sáenz (1973). & \\
${ }^{\mathrm{b}}$ See text for discussion. & \\
\end{tabular}

the southwest. The lowermost unit, LU-1, shows a very irregular fan shape, and LU-2, a more regular fan shape with its apex at the crater. The calculated volume of all LU deposits is $21.0 \pm 4.0 \times 10^{6} \mathrm{~m}^{3}$. In addition, $1.8 \pm 0.5 \times 10^{6} \mathrm{~m}^{3}$ was estimated as the volume of the block and ash flows by Melson and Sáenz, 1973. There are contradictions in previous calculations of airfall tephra volumes, since Melson and Sáenz (1973) ascribe a volume of $40 \pm 20 \times 10^{6} \mathrm{~m}^{3}$ to the "airfall apron from 4 to $20 \mathrm{~km}$ west" and only $3 \pm 1 \times 10^{6} \mathrm{~m}^{3}$ to the "airfall apron from 0 to $4 \mathrm{~km}$ west". We infer these figures are reversed, as the lower figure roughly agrees with the estimates from scattered data by Sáenz (1977, Table 1, p. 159). If we assume that the estimate of $3 \pm 1 \times 10^{6} \mathrm{~m}^{3}$ for the " $4-20 \mathrm{~km}$ west" airfall tephra is correct, a total bulk volume of the ejected pyroclastic material is $25.8 \pm 5.5 \times 10^{6} \mathrm{~m}^{3}$ (Table 4). Subtracting the volume of lithics, which averages $7 \%$ for all the deposits studied (obtained from volume prorating in Table 2) and a $30 \%$ of estimated porosity, we obtain a total volume of $16.3 \pm 3.5 \times 10^{6} \mathrm{~m}^{3}$ of juvenile material with an average density of $1.55 \mathrm{~g} \mathrm{~cm}^{-3}$. Then, we calculate a dense rock equivalent (DRE, $2.7 \mathrm{~g} \mathrm{~cm}^{-3}$ in this case) of $9.4 \pm 2.0 \times 10^{6} \mathrm{~m}^{3}$ of juvenile magma ejected. This is the volume of a cylindrical body of dense rock with a diameter of $100 \mathrm{~m}$ and a length of $1200 \mathrm{~m}$.

\section{Petrochemistry}

The 1968 eruption products are high-Al, low-K andesites near the calc-alkaline/tholeiitic field series boundary. Plagioclase phenocrysts $\left(\mathrm{An}_{94-47}\right)$ are up to $2.5 \mathrm{~cm}$ long, distributed in two groups: (1) granular texture with rounded clots of glomeroporphyritic plagioclase with some reverse but usually normally and oscillatory zoning, and rich in glass and fluid inclusions; (2) more- or less-tabular euhedral plagioclase with clinopyroxene inclusions. Augite is common as euhedral to anhedral microphenocrysts and phenocrysts $\left(\mathrm{Wo}_{39} \mathrm{En}_{44} \mathrm{Fs}_{17}\right)$ as big as $2 \mathrm{~mm}$. Euhedral orthopyroxene $\left(\mathrm{Wo}_{2} \mathrm{En}_{69-76} \mathrm{Fs}_{24-27}\right)$ up to $1.5 \mathrm{~cm}$ is present (ca. 4\%), some with normal to reverse zoning. Olivine phenocrysts $\left(\mathrm{Fo}_{69-83}\right)$ are rare $(0-0.1 \%)$ and are rimmed by orthopyroxene. Hornblende as big as $10 \mathrm{~mm}$ (magnesio-hastingsite: $<0.2 \%$ ) have opacitized rims. Titanomagnetite microphenocrysts are rare. The intergranular groundmass has clinopyroxene and $\mathrm{Fe}-\mathrm{Ti}$ oxides. The vesiculated clasts are chemically indistinguishable in terms of both major and trace element concentrations from the dense juvenile ballistic blocks, and from juvenile components in the subsequent block and ash flow deposits (Melson and Sáenz, 1968; Reagan et al., 1987).

The 1968 eruption tephras offer an insight into the magma chamber. An interval sampling of these tephras allows us to examine their geochemical evolution. Assuming an uncomplicated draw down, the tephra sequence can be inverted to represent the original sequence in the magma chamber. The tephra at the bottom of the sequence (sample 68-17-1 in the BL, Table 5), the first to erupt, would be at the top of the magma chamber, and the tephra at the top of the sequence (sample 68-17-8 in the LU-3), the last to erupt, would be at the bottom of the magma chamber. In analyzing the geochemical data, the tephras are oriented in their position in the magma chamber.

The major elements indicate that some crystal redistribution occurred prior to the eruption. $\mathrm{MgO}$ and $\mathrm{FeO}$ concentrations increase downwards indicating settling of ferromagnesian minerals at the bottom of the magmatic sequence. Interestingly, $\mathrm{CaO}$ also increases down section, indicating that clinoproxene is the main ferromagnesian mineral in the tephras. $\mathrm{TiO}_{2}$ also increases down section but reaches a maximum in the tephra interval above that of the $\mathrm{FeO}$ and $\mathrm{MgO}$ maximum. $\mathrm{TiO}_{2}$ is proxy for magnetite in the magma. Elements $\mathrm{Sc}, \mathrm{Ni}, \mathrm{V}, \mathrm{Cr}$ and $\mathrm{Co}$ show an increase, downwards through the magma chamber as well. These trace elements incorporate into mafic minerals such as pyroxenes and oxides. $\mathrm{Al}_{2} \mathrm{O}_{3}$ shows a maximum at DAU-1 (sample 68-17-4), and decreases both upwards and downwards from this unit. This maximum provides evidence for a plagioclase-enriched unit. Plagioclase has a lower density compared to other minerals present and can even become buoyant if gas bubbles nucleate on it. At any rate, plagioclase will sink more slowly than mafic minerals due to its low density. $\mathrm{Eu}$ and $\mathrm{Sr}$ also show a maximum concentration at the top of LU-1 (6817-3) and DAU-1 (68-17-4), respectively, supporting the plagioclase enrichment. 
Table 5

Geochemistry of the samples from 1968 eruption. Major elements in wt.\%, trace elements in ppm

\begin{tabular}{|c|c|c|c|c|c|c|c|c|c|c|c|c|}
\hline Sample & Unit & $\mathrm{SiO}_{2}$ & $\mathrm{TiO}_{2}$ & $\mathrm{Al}_{2} \mathrm{O}_{3}$ & $\mathrm{FeO}$ & $\mathrm{MnO}$ & $\mathrm{MgO}$ & $\mathrm{CaO}$ & $\mathrm{Na}_{2} \mathrm{O}$ & $\mathrm{K}_{2} \mathrm{O}$ & $\mathrm{P}_{2} \mathrm{O}_{5}$ & $\mathrm{Li}$ \\
\hline $68-17-1$ & $\mathrm{BL}$ & 56.3 & 0.54 & 20.6 & 5.97 & 0.14 & 2.71 & 8.66 & 3.41 & 0.72 & 0.12 & 9.30 \\
\hline $68-17-2$ & LU-1 & 56.8 & 0.53 & 20.6 & 6.02 & 0.14 & 2.65 & 8.71 & 3.37 & 0.69 & 0.13 & 8.64 \\
\hline $68-17-3$ & LU-1 & 56.3 & 0.53 & 20.4 & 6.02 & 0.14 & 2.63 & 9.01 & 3.42 & 0.72 & 0.16 & 9.13 \\
\hline $68-17-4$ & DAU-1 & 56.5 & 0.54 & 20.8 & 6.05 & 0.13 & 2.64 & 9.07 & 3.34 & 0.67 & 0.18 & 8.73 \\
\hline $68-17-5$ & LU-2 & 56.3 & 0.54 & 20.7 & 6.06 & 0.13 & 2.74 & 9.05 & 3.31 & 0.64 & 0.17 & 8.70 \\
\hline $68-17-6$ & LU-2 & 56.3 & 0.56 & 20.4 & 6.46 & 0.14 & 2.92 & 9.00 & 3.29 & 0.66 & 0.16 & 8.46 \\
\hline $68-3-7$ & LU-3 & 56.0 & 0.54 & 20.1 & 6.45 & 0.15 & 3.05 & 9.21 & 3.28 & 0.63 & 0.16 & 8.46 \\
\hline $68-17-8$ & LU-3 & 57.0 & 0.54 & 20.8 & 6.03 & 0.14 & 2.73 & 9.21 & 3.34 & 0.65 & 0.16 & 9.40 \\
\hline Sample & $\mathrm{Rb}$ & $\mathrm{Sr}$ & $\mathrm{Y}$ & $\mathrm{Zr}$ & $\mathrm{Nb}$ & Mo & Cs & $\mathrm{Ba}$ & $\mathrm{La}$ & $\mathrm{Ce}$ & $\operatorname{Pr}$ & $\mathrm{Nd}$ \\
\hline $68-17-1$ & 11.4 & 668 & 16.7 & 54.6 & 3.85 & 1.23 & 0.27 & 551 & 11.4 & 24.3 & 3.46 & 13.5 \\
\hline $68-17-2$ & 9.69 & 671 & 15.9 & 53.0 & 3.71 & 1.19 & 0.27 & 531 & 10.8 & 23.3 & 3.28 & 12.9 \\
\hline $68-17-3$ & 11.9 & 666 & 16.8 & 53.9 & 3.80 & 1.30 & 0.30 & 562 & 11.4 & 24.4 & 3.45 & 13.5 \\
\hline $68-17-4$ & 10.6 & 689 & 16.2 & 51.8 & 3.68 & 1.14 & 0.28 & 537 & 11.0 & 23.6 & 3.3 & 13.0 \\
\hline $68-17-5$ & 9.96 & 660 & 15.7 & 50.6 & 3.63 & 1.18 & 0.28 & 531 & 10.8 & 23.1 & 3.26 & 12.8 \\
\hline $68-17-6$ & 10.6 & 635 & 15.7 & 52.4 & 3.67 & 1.15 & 0.26 & 528 & 11.0 & 23.3 & 3.28 & 13.0 \\
\hline $68-3-7$ & 10.8 & 630 & 15.8 & 51.0 & 3.60 & 1.14 & 0.27 & 527 & 10.8 & 22.7 & 3.23 & 12.8 \\
\hline $68-17-8$ & 11.1 & 686 & 15.8 & 50.3 & 3.63 & 1.13 & 0.31 & 542 & 11.0 & 23.7 & 3.31 & 13.0 \\
\hline Sample & $\mathrm{Sm}$ & $\mathrm{Eu}$ & $\mathrm{Gd}$ & $\mathrm{Tb}$ & $\mathrm{y}$ & Ho & $\mathrm{Er}$ & $\mathrm{Tm}$ & $\mathrm{Yb}$ & $\mathrm{Lu}$ & $\mathrm{Hf}$ & $\mathrm{Ta}$ \\
\hline $68-17-1$ & 3.19 & 1.00 & 3.00 & 0.46 & 2.82 & 0.57 & 1.65 & 0.26 & 1.61 & 0.25 & 1.56 & 0.24 \\
\hline $68-17-2$ & 3.06 & 1.01 & 2.95 & 0.45 & 2.68 & 0.55 & 1.58 & 0.24 & 1.54 & 0.24 & 1.50 & 0.23 \\
\hline $68-17-3$ & 3.19 & 1.04 & 3.08 & 0.47 & 2.80 & 0.57 & 1.65 & 0.26 & 1.62 & 0.26 & 1.53 & 0.24 \\
\hline $68-17-4$ & 3.06 & 1.03 & 3.00 & 0.45 & 2.70 & 0.55 & 1.59 & 0.25 & 1.57 & 0.25 & 1.46 & 0.24 \\
\hline $68-17-5$ & 3.06 & 1.02 & 2.98 & 0.45 & 2.69 & 0.55 & 1.57 & 0.24 & 1.55 & 0.24 & 1.45 & 0.23 \\
\hline $68-17-6$ & 3.05 & 1.02 & 3.01 & 0.45 & 2.67 & 0.55 & 1.57 & 0.24 & 1.57 & 0.25 & 1.50 & 0.23 \\
\hline $68-3-7$ & 3.06 & 1.01 & 3.01 & 0.46 & 2.70 & 0.55 & 1.58 & 0.25 & 1.56 & 0.25 & 1.44 & 0.24 \\
\hline $68-17-8$ & 3.08 & 1.05 & 3.04 & 0.46 & 2.69 & 0.55 & 1.59 & 0.25 & 1.56 & 0.25 & 1.46 & 0.24 \\
\hline Sample & W & $\mathrm{Tl}$ & $\mathrm{Pb}$ & $\mathrm{Th}$ & $\mathrm{U}$ & $\mathrm{Sc}$ & $\mathrm{V}$ & $\mathrm{Cr}$ & $\mathrm{Co}$ & $\mathrm{Ni}$ & $\mathrm{Cu}$ & $\mathrm{Zn}$ \\
\hline $68-17-1$ & 0.30 & 0.04 & 3.16 & 0.94 & 0.38 & 15.6 & 147 & 9.55 & 16.1 & 8.04 & 43.9 & 73.3 \\
\hline $68-17-2$ & 0.29 & 0.04 & 3.10 & 0.88 & 0.37 & 14.6 & 126 & 5.00 & 14.7 & 6.19 & 45.1 & 68.0 \\
\hline $68-17-3$ & 0.30 & 0.04 & 3.23 & 0.96 & 0.38 & 15.4 & 138 & 5.93 & 15.4 & 7.53 & 75.8 & 71.4 \\
\hline $68-17-4$ & 0.30 & 0.04 & 3.15 & 0.90 & 0.37 & 14.7 & 131 & 5.96 & 14.9 & 6.54 & 71.3 & 68.3 \\
\hline $68-17-5$ & 0.30 & 0.04 & 3.08 & 0.90 & 0.35 & 15.2 & 129 & 6.85 & 14.9 & 7.64 & 40.9 & 66.1 \\
\hline $68-17-6$ & 0.32 & 0.04 & 3.08 & 0.90 & 0.36 & 15.0 & 132 & 6.82 & 15.6 & 8.83 & 46.0 & 68.9 \\
\hline $68-3-7$ & 0.33 & 0.04 & 3.27 & 0.91 & 0.36 & 16.8 & 143 & 8.96 & 16.2 & 9.23 & 69.7 & 68.2 \\
\hline $68-17-8$ & 0.29 & 0.04 & 3.11 & 0.93 & 0.37 & 15.3 & 130 & 6.38 & 14.7 & 7.07 & 69.9 & 67.1 \\
\hline
\end{tabular}

If minerals are settling to the bottom of the magma, there should be an increase in incompatible elements towards the top of the magma. Unfortunately, the vulnerability of tephras to weathering has destroyed any trends that may have been seen in the most mobile incompatible elements such as $\mathrm{U}, \mathrm{Pb}, \mathrm{Cs}$ and $\mathrm{Rb}$. This incompatible trend can be seen in the more abundant trace elements such as $\mathrm{Ba}$ and the less mobile LREE. This increasing upwards trend is most evident in the abundant incompatible oxides, $\mathrm{SiO}_{2}, \mathrm{Na}_{2} \mathrm{O}$ and $\mathrm{K}_{2} \mathrm{O}$. It can also be seen extremely well in the HFSE, Nb, Zr, Hf, Mo and Zn, which are relatively immobile yet still very incompatible. Looking at the major elements, there are a few strange samples. The youngest sample, at the top of LU-3 (68-17-
8), seems completely foreign to all the compatible element trends. It has much lower concentrations of $\mathrm{MgO}, \mathrm{FeO}$, $\mathrm{Sc}, \mathrm{Ni}, \mathrm{V}, \mathrm{Cr}$ and $\mathrm{Co}$, and elevated concentrations of $\mathrm{Al}_{2} \mathrm{O}_{3}, \mathrm{Sr}$ and $\mathrm{Eu}$. There may have been a plagioclase phenocryst in one of the tephras powdered for this sample. Arenal's andesitic tephras often have phenocrysts in them, which may be the cause of some of the strange element concentrations in a few of the tephras.

\section{Discussion}

Based on the stratigraphy and sedimentological features of LU, the sequence and style of the eruption appear to be a lateral blast (high-velocity, dry pyroclastic surge) 
explosions, which commonly occur by sudden decompression of highly pressurized magma (cf. Druitt, 1992; Rosi, 1996; Valentine and Fisher, 2000). The 1968 eruption can be reconstructed as follows (Figs. 4 and 9).

\subsection{The basal layer}

These layers were definitely transported laterally as proved by the poor sorting, the local thickening upstream of trees and the unbedded nature, where the basal pumice represents the uppermost level of the magma column. The BL are very similar to those described by Fisher et al. (1987) and Fisher (1990) as the layer $\mathrm{A}_{0}$ from the May 18, $1980 \mathrm{Mt}$. St. Helens blast eruption, interpreted to have formed by shearing at the base of the head of the blast surge (in our case the LU) in the region between the front and the back of the head of the blast surge. According to Minakami et al. (1969),

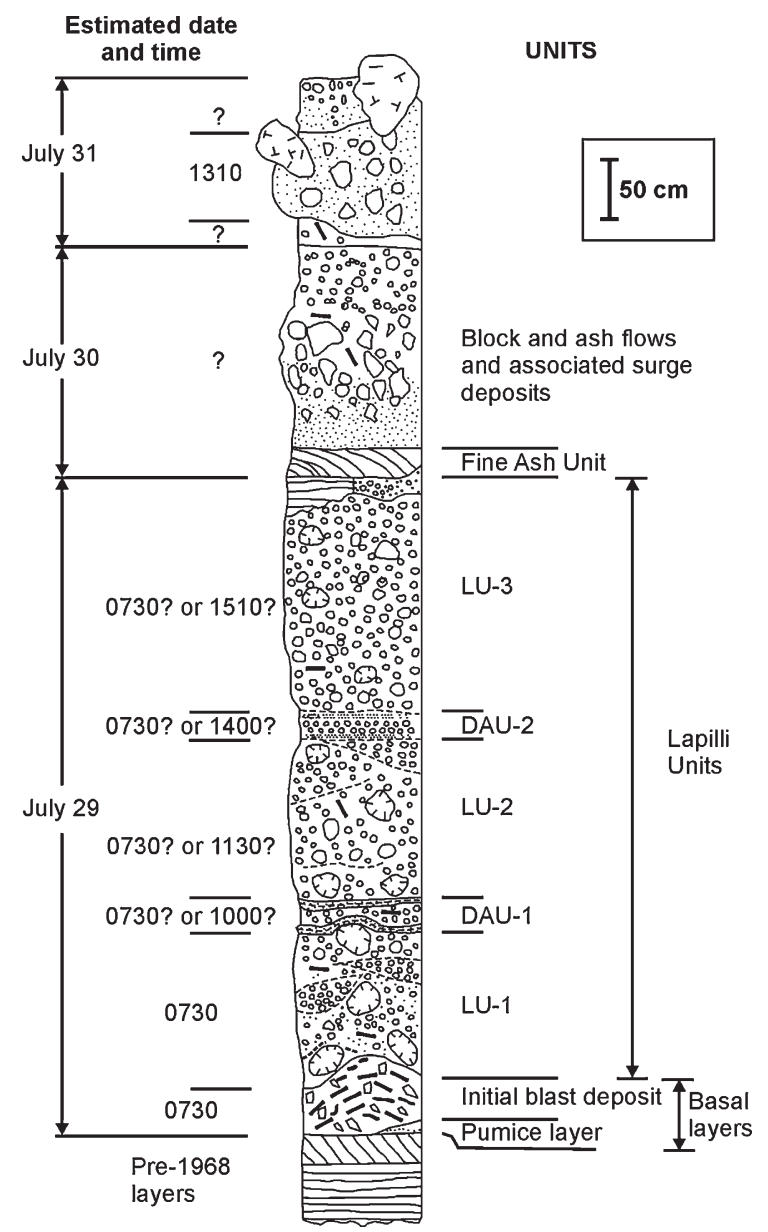

Fig. 9. Summary stratigraphic column based principally on localities 3 , 4, 5, 16, 17 and 21 (see Fig. 2 for locality numbers) and estimated date and time of each eruptive unit. Same symbols as Fig. 5.
Pueblo Nuevo and Tabacón were affected by strong air blasts just prior to the heavy fall of fine ejecta. One eyewitness survivor reported that he was near Tabacón (outside the devastation zone) at the time of the first explosion. He saw "landslides" on the side of the volcano just below the site where the lower crater was formed and that these were immediately followed by a violent ground-shaking explosion. The explosion produced a dark ash cloud, which descended from a site above the landslide. After that, he was engulfed by warm, acrid-smelling air and ash, and was violently thrown to the ground by the high velocity of the wind and ash (Melson and Sáenz, 1968).

\subsection{The $L U$ and $D A U$}

Although several major explosions that lasted for several minutes occurred on the first day, we do not have any evidence to discern if the whole LU where formed simultaneously or during more than $7 \mathrm{~h}$ of the eruption during the first day. However, if we compare the 1980 Mount St. Helens blast eruption with 1968 Arenal eruption, we could expect that the first opening event produced the BL and the LU, representing short pulses in a few minutes. Interestingly, the lithology of LU-1 to -3 differs in many aspects. Despite that Melson and Sáenz (1968) interpreted most, if not all explosions originated from crater A, perhaps each LU layer could represent the opening and activity of a new crater (craters A, B and C, respectively, for LU-1, -2 and -3 ). The dense juvenile fragments are particularly more abundant in the medium facies of LU-1. The fact that the content of this kind of clasts in LU-1 increases along distance, opposite to LU-2 and mainly LU-3, suggests that the energy of bombardment dropped as a function of time. A lava plug (quenched or degassed) should have broken and ejected as dense pyroclasts under higher energy conditions during the deposition of LU-1, resulting in the impact fragmentation of long-distance large ballistic bombs, incorporated to the early explosive phase deposits in medium facies. While eruption continued, such clasts were only incorporated in more proximal facies of the LU.

The following changes were observed with increasing distance from the source: (a) the juvenile (vesiculated and dense) bomb and lapilli content decreases, except for LU-1 in proximal facies; (b) the non-juvenile blocks (mostly fresh accidental lithics) content sharply decreases; (c) the ash matrix increases; and (d) LU-1 contains more hydrothermally altered lithics close to the lower crater than the upper two layers LU-2 and -3 (Fig. 10 and summary in Fig. 12). 

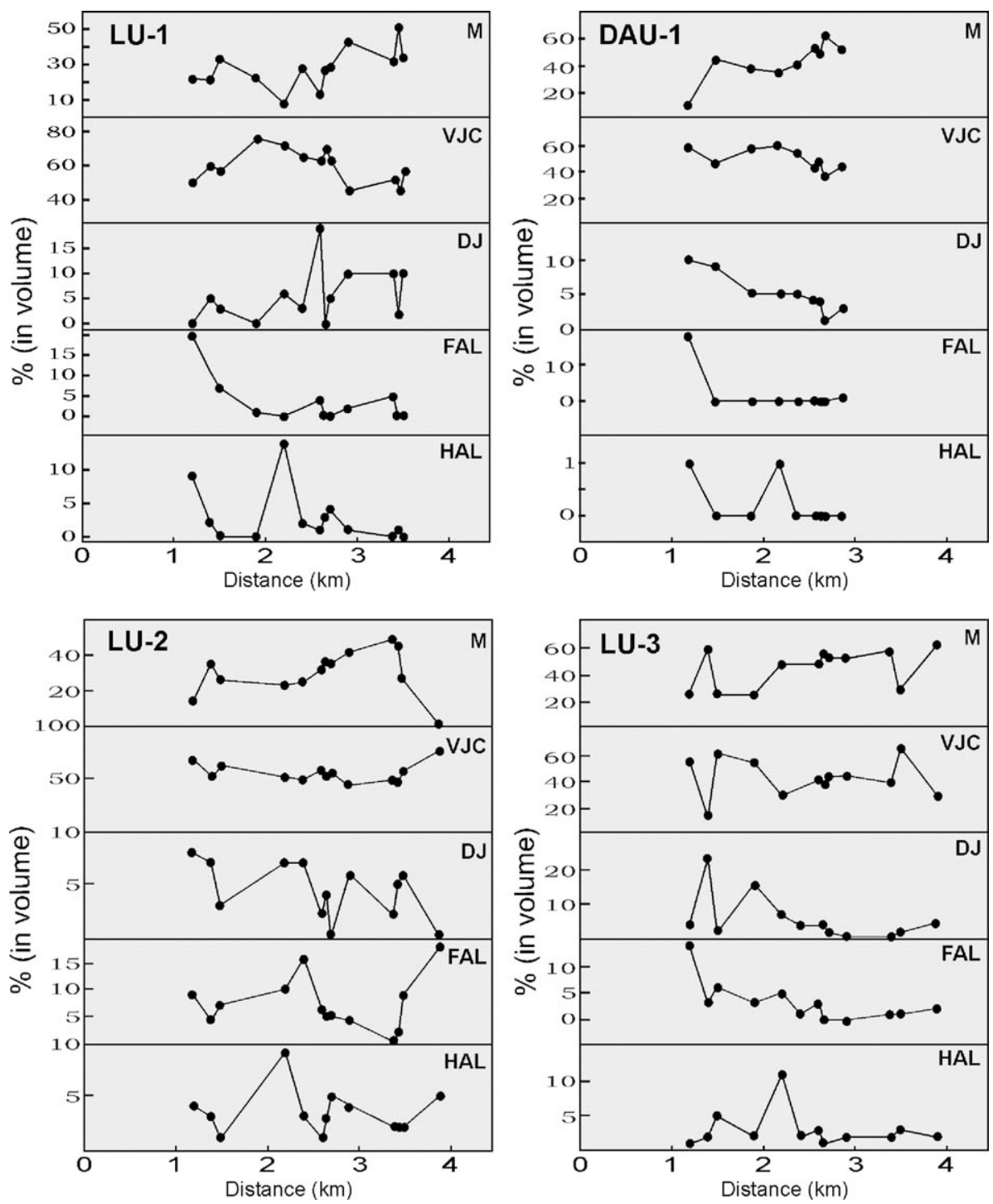

Fig. 10. Volume percentage of components of the different units, as function of distance from the lowest crater A. M: Matrix (ash to fine lapilli size), VJ: vesiculated juvenile clasts, DJ: dense juveniles, FAL: fresh accidental lithics, HAL: hydrothermally altered lithics.

When sorting is plotted against the mean grain size (Fig. 11), all the 1968 LU samples are within the tephra fall deposits and more than half are within the overlapping field of surges. The unconsolidated LU juvenile components range from subangular to rounded, and the deposits in the proximal parts mantle the landscape and show an internal diffuse horizontal stratification, discrete cross-bedding, reverse grading of coarse fragments, intermixing of soil and vegetative debris, and in the distal part of the pyroclastic fan, show fine-coarse lapilli deposition behind obstacles and/or thinner tephra deposits to coarse, dune-like structures in front of the obstacles (Fig. 6e). Examples at Pueblo Nuevo village are trees and fence poles clearly charred only in the face exposed toward the volcano. It was observed in outcrops exposed during the period of the lowest water level of Arenal lake (January 1994, Figs. 2 and 6e). In fact, Minakami et al. (1969) wrote: "Pueblo Nuevo and Tabacón, the center of accumulation of fine ejecta, were attacked by strong air blast like air hammer just before heavy fall of fine ejecta. Therefore, it would be reasonable to assume that the distribution of fine ejecta in the present eruption is made not by wind transportation but by another dynamical mechanism". Also, Melson and Sáenz (1973) said that the nuées ardentes at Arenal produced other effects that may be viewed as the result of a "directed blast". 


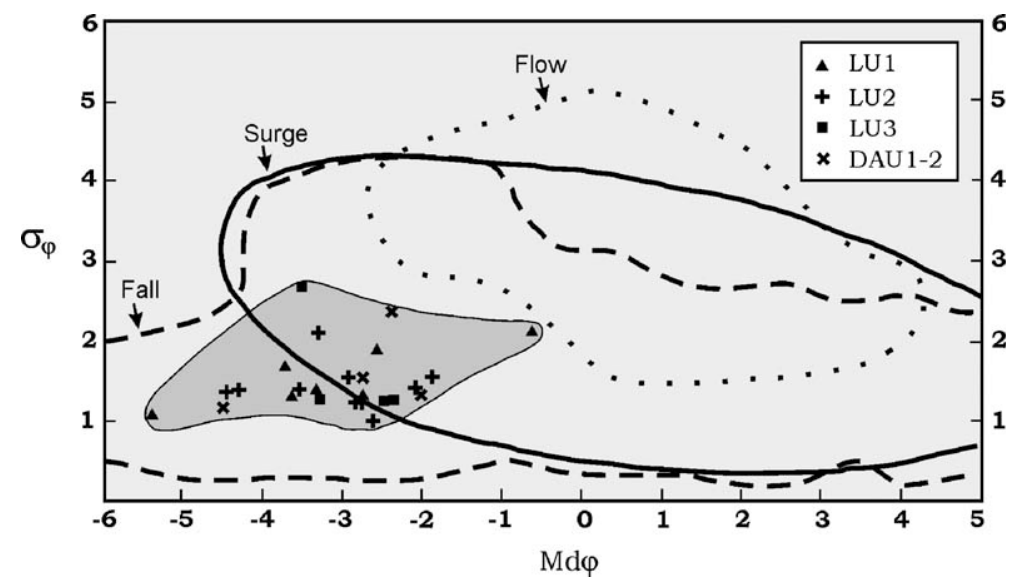

Fig. 11. $\mathrm{Md}_{\Phi}$ versus $\sigma_{\Phi}$ diagram for the LU samples of Arenal 1968, shown into the dark gray area. The boundary fields (shown by $1 \%$ contours) were redrawn for pyroclastic fall (after Walker, 1971; Sparks and Wright, 1979; Lirer and Vinci, 1991) and flow (Walker, 1971). Solid line encompasses surge deposits (Fisher and Schmincke, 1984).

Many beds contain intermixed vegetation and soil fragments. A tempting interpretation of these layers is that they may represent the opening of a new crater and the lateral expansion of pyroclasts, in which the top layer of soil and vegetation fragments overlying massive sandy tuff were excavated by a steam eruption and transported laterally in some form of a blast, in which the ash-rich gray layer must be an external phase of the eruption. Locally, these layers could represent a spray of soil and vegetation fragments from a heavy continuous rain of large ballistic fragments impacting the ground. Nevertheless, the well-defined and continuous distribution of the thin brown ash horizons in the DAU and between major LU (LU-1/2 and LU-2/3), more or less at the axis of the pyroclastic fan (localities $8,9,14,15$ and 22), can only be explained by a tractional and erosive, pyroclastic current, possibly associated with pressure explosion waves and associated surge events. The non-carbonized wood debris in the LU could be due to falling leaves and small branches during the fallout and ballistic events. However, small branches in the LU show a strong horizontal orientation in the crater direction, suggesting some lateral component (Fig. 1). The existence of some splintered tree trunks and vegetation within the devastated zone with a strongly directed fabric, and a thin tephra deposit, again suggests a strong lateral component of the explosion. Changes of lateral facies with distance from vent include: cross-stratification occurring closest to the vent; dominantly massive, structureless or planar beds occur at proximal and medium facies. All these characteristics suggest a blast surge ejected at high speed in grain-by-grain tractional transport, implying low grain concentration in the transporting media, as was suggested in other similar deposits (Tables 6 and 7).

The isopach map patterns presented here show not only a strong unidirectional wind direction, but also a rapid longitudinal and transversal decrease in thickness, and some topographic control, suggesting a different transport mode than exclusively fallout (Figs. 5 and 8).

Some rounded bombs and blocks that, possibly rolling, picked-up fragments during the lateral transport, were also progressively fragmented on steep slopes of the volcano. The poor sorting (large bombs/blocks together with lapilli and ash) resulted by such a process. Some large fragments, interpreted as fall deposits, probably entered the moving cloud from above as it sped away from the source. The grain size inflection detected at $\leq 2.5 \mathrm{~km}$ (Fig. 7) from the source is coincident with an increase of the vesicular lapilli content. After $2.5 \mathrm{~km}$, the vesicular lapilli progressively decrease and the fresh accidental lithics decrease. The sorting characteristically improves in LU-2 and -3 at the farthest distance from vent, which is presumably related to a general decrease in turbulence and greater uniformity of conditions as the laterally emplaced and fallout tephra traveled farther from vent.

In general, the features of LU are consistent with suspension sedimentation under rapidly waning, highly concentrated conditions. The poor to moderate sorting and polymodal size distribution could be interpreted as characteristic of deposition from concentrated, polydisperse suspension without formation of traction-related bedforms or sorting of different grain sizes by turbulence (see Druitt, 1992). However, the ballistic is still a present problem to recognize if these processes happened or not. The open-work texture could be 
Table 6

Comparison between some features of historic blasts (in chronological order)

\begin{tabular}{|c|c|c|c|c|c|c|c|c|c|c|c|}
\hline Volcano & $\begin{array}{l}\text { Bandai } \\
\text { (Japan) }\end{array}$ & $\begin{array}{l}\text { Mt. Pelée } \\
\text { (Martinique) }\end{array}$ & $\begin{array}{l}\text { Lassen Peak } \\
\text { (U.S.A.) }\end{array}$ & $\begin{array}{l}\text { Mt. Lamington } \\
\text { (Papua New } \\
\text { Guinea) }\end{array}$ & $\begin{array}{l}\text { Bezymianny } \\
\text { (Kamchatka) }\end{array}$ & $\begin{array}{l}\text { Shiveluch } \\
\text { (Kamchatka) }\end{array}$ & $\begin{array}{l}\text { Arenal } \\
\text { (Costa Rica) }\end{array}$ & $\begin{array}{l}\text { Mt. St. } \\
\text { Helens } \\
\text { (U.S.A.) }\end{array}$ & $\begin{array}{l}\text { Pinatubo } \\
\text { (Philippines) }\end{array}$ & $\begin{array}{l}\text { Soufrière Hills } \\
\text { (Montserrat) }\end{array}$ & \\
\hline References & $\begin{array}{l}\text { Glicken and } \\
\text { Nakamura } \\
\text { (1988) }\end{array}$ & $\begin{array}{l}\text { Fisher and } \\
\text { Heiken } \\
\text { (1982), Smith } \\
\text { and Roobol } \\
(1990)\end{array}$ & $\begin{array}{l}\text { Eppler (1987), } \\
\text { Eppler and Malin } \\
\text { (1989) }\end{array}$ & Taylor (1958) & Belousov (1996) & Bogoyavlenskaya et al. (1985) & This work & $\begin{array}{l}\text { Kieffer } \\
(1981), \\
\text { Fisher et al. } \\
\text { (1987), } \\
\text { Druitt } \\
(1992)\end{array}$ & $\begin{array}{l}\text { Hoblitt et al. } \\
\text { (1996) }\end{array}$ & $\begin{array}{l}\text { Druitt and } \\
\text { Kookelaar (2002) }\end{array}$ & $\begin{array}{l}0 \\
i \\
0\end{array}$ \\
\hline Date & $\begin{array}{l}\text { July } 15 \\
1888\end{array}$ & $\begin{array}{l}1902 \\
(20 \text { May) }\end{array}$ & 1915 (22 May) & 1951 & 1956 (30 March) & $\begin{array}{l}1964 \\
\text { (12 November) }\end{array}$ & $\begin{array}{l}1968 \\
\text { (29 July) }\end{array}$ & $\begin{array}{l}1980 \\
(18 \text { May) }\end{array}$ & $\begin{array}{l}1991 \\
\text { (June 14) }\end{array}$ & $\begin{array}{l}1997(25-26 \\
\text { December })\end{array}$ & $\begin{array}{l}5 \\
\vdots \\
\vdots \\
\vdots\end{array}$ \\
\hline $\begin{array}{l}\text { Dormancy period } \\
\text { (years, partially } \\
\text { based on Simkin } \\
\text { and Siebert, 1994) }\end{array}$ & 101 & 50 & $\begin{array}{l}279 \text { ( } 64 \text { yr for a } \\
\text { cinder cone) }\end{array}$ & $\leq 6800$ & $\sim 1000$ & 20 & $\sim 300-450$ & $123 ?$ & $\sim 676$ & $\sim 365$ & $\begin{array}{c}0 \\
2 \\
2 \\
2 \\
\vdots \\
\vdots \\
2\end{array}$ \\
\hline $\begin{array}{l}\text { Duration and } \\
\text { number of events }\end{array}$ & $\begin{array}{l}15-20 \\
\text { explosions }\end{array}$ & - & $\begin{array}{l}\text { At least two or three } \\
\text { events ( } 19-22 \text { May), } \\
\text { separated by } 1 \text { day of } \\
\text { relative paucity; blast } \\
\text { was the latest. }\end{array}$ & Single event & - & - & $\begin{array}{l}\text { Numerous } \\
\text { events } \\
\text { separated by } \\
\text { tens of } \\
\text { minutes to } \\
\text { hours }\end{array}$ & $\begin{array}{l}\text { Single event } \\
\text { or perhaps } \\
\text { two events }\end{array}$ & $\begin{array}{l}\text { Numerous } \\
\text { events separated } \\
\text { by tens of } \\
\text { minutes to } \\
\text { hours }\end{array}$ & Two events & $\begin{array}{c}\frac{5}{3} \\
\frac{5}{3} \\
\frac{5}{0} \\
\frac{5}{5}\end{array}$ \\
\hline $\begin{array}{l}\text { Maximum extension } \\
\quad(\mathrm{km})\end{array}$ & - & 5.3 & 7.0 & 13 & 29 & - & 5.5 & 30 & 19 & 3.5 & 3 \\
\hline $\begin{array}{l}\text { Devastated area } \\
\left(\mathrm{km}^{2}\right)\end{array}$ & 13 & $\gg 40$ & $\sim 7$ & $180-260(230)$ & 500 & - & 15 & $500-600$ & 300 & 10 & $\begin{array}{c}0 \\
5 \\
5 \\
5 \\
5\end{array}$ \\
\hline Distribution & Lateral & $\begin{array}{l}\text { Lateral } \\
\left(\sim 50^{\circ}\right)\end{array}$ & Lateral $\left(20^{\circ}\right)$ & Radial & Lateral $\left(\sim 110^{\circ}\right)$ & Lateral & $\begin{array}{l}\text { Lateral } \\
\left(\sim 85^{\circ}\right)\end{array}$ & $\begin{array}{l}\text { Azimuthally } \\
\left(180^{\circ}\right)\end{array}$ & Radial & Lateral $\left(70^{\circ}\right)$ & 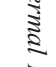 \\
\hline Composition & $\begin{array}{l}\text { No juvenile } \\
\text { material }\end{array}$ & Andesite & Dacite & Andesite? & Andesite & Andesite? & Andesite & Dacite & Dacite & Andesite & $\begin{array}{l}\overrightarrow{0} \\
0 \\
0 \\
8\end{array}$ \\
\hline Juvenile clast (\%) & 0 & 90 & $4-84$ & - & $70-95(84)$ & - & 90 & $20-90(60)$ & - & $30-40$ & $\frac{\sqrt{2}}{\sqrt[3]{2}}$ \\
\hline Volume $\left(\mathrm{km}^{3}\right)$ & 0.011 & - & - & - & $0.2-0.4$ & - & 0.01 & 0.2 & - & 0.009 & हुँ \\
\hline Velocity $\left(\mathrm{m} \mathrm{s}^{-1}\right)$ & - & - & - & - & $>60$ & - & - & $\begin{array}{l}150-235 \\
\text { Sector }\end{array}$ & - & 13-22 & $\stackrel{2}{N}$ \\
\hline $\begin{array}{l}\text { Eruption type } \\
\text { and comments }\end{array}$ & $\begin{array}{l}\text { Lateral } \\
\text { "phreatic" } \\
\text { blast related } \\
\text { to sector } \\
\text { collapse }\end{array}$ & $\begin{array}{l}\text { Cryptodome } \\
\text { explosion? }\end{array}$ & $\begin{array}{l}\text { Physical disruption } \\
\text { (Vulcanian type) and } \\
\text { avalanching of lava } \\
\text { flow, with intimate } \\
\text { mixing and heat } \\
\text { exchange between } \\
\text { hot fragments and } \\
\text { snow }\end{array}$ & $\begin{array}{l}\text { Directed } \\
\text { fountains that } \\
\text { collapse }\end{array}$ & $\begin{array}{l}\text { Sector collapse and } \\
\text { exposed a } \\
\text { crytodome. The } \\
\text { surges resemble } \\
\text { those of Mt. St. } \\
\text { Helens }\end{array}$ & Sector collapse & $\begin{array}{l}\text { Lateral } \\
\text { explosion }\end{array}$ & $\begin{array}{l}\text { Sector } \\
\text { collapse and } \\
\text { exposed a } \\
\text { crytodome }\end{array}$ & $\begin{array}{l}\text { Directed } \\
\text { fountains that } \\
\text { collapse. The } \\
\text { surges resemble } \\
\text { those of } \\
\text { Mt. Lamington }\end{array}$ & $\begin{array}{l}\text { Debris avalanche } \\
\text { and dome } \\
\text { collapse. The } \\
\text { surges resemble } \\
\text { those of } \\
\text { Mt. St. Helens }\end{array}$ & 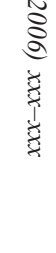 \\
\hline Sorting & - & - & -2.6 to $1.6 \varnothing$ & - & - & - & $1.00-2.65$ & $1.0-2.1$ & - & $0.2-1.8$ & \\
\hline \multirow{3}{*}{$\begin{array}{l}\text { Layers (Fisher } \\
\text { et al., 1987) }\end{array}$} & $\mathrm{x}$ & $\mathrm{x}$ & $?$ & $\mathrm{x}$ & $?$ & - & $\mathrm{x}$ & $\mathrm{x}$ & - & $\mathrm{x}$ & \\
\hline & $\mathrm{x}$ & $\mathrm{x}$ & $\mathrm{x}$ & $\mathrm{x}$ & $\mathrm{x}$ & - & $\mathrm{x}$ & $\mathrm{x}$ & $\mathrm{x}$ & $\mathrm{x}$ & \\
\hline & $\mathrm{x}$ & $\mathrm{x}$ & $\mathrm{x}$ & $\mathrm{x}$ & $\mathrm{x}$ & - & $\mathrm{x}$ & $\mathrm{x}$ & $\mathrm{x}$ ? & - & \\
\hline
\end{tabular}


Table 7

Comparison between some features of prehistoric blasts (in chronological order)

\begin{tabular}{|c|c|c|c|c|c|c|c|c|c|c|}
\hline Volcano & $\begin{array}{l}\text { Taunshits } \\
\text { (Kamchatka) }\end{array}$ & $\begin{array}{l}\text { Avacha } \\
\text { (Kamchatka) }\end{array}$ & $\begin{array}{l}\text { Popocatépetl } \\
\text { (Mexico) }\end{array}$ & $\begin{array}{l}\text { Guagua } \\
\text { Pichincha } \\
\text { (Ecuador) }\end{array}$ & $\begin{array}{l}\text { La Soufrière } \\
\text { (Guadeloupe) }\end{array}$ & $\begin{array}{l}\text { Cerro Quemado } \\
\text { (Guatemala) }\end{array}$ & Pacaya (Guatemala) & $\begin{array}{l}\text { Ixhuatán } \\
\text { (Guatemala) }\end{array}$ & $\begin{array}{l}\text { Augustine } \\
\text { (Alaska) }\end{array}$ & $\begin{array}{l}\text { Hokkaido } \\
\text { Komagatake } \\
\text { (Japan) }\end{array}$ \\
\hline References & $\begin{array}{l}\text { Melekestsev } \\
\text { et al. (1990) }\end{array}$ & $\begin{array}{l}\text { Melekestsev } \\
\text { et al. (1992) }\end{array}$ & $\begin{array}{l}\text { Siebe et al. } \\
(1995)\end{array}$ & $\begin{array}{l}\text { Barberi et al. } \\
\text { (1992) }\end{array}$ & $\begin{array}{l}\text { Boudon et al. } \\
(1987,1989)\end{array}$ & $\begin{array}{l}\text { Conway et al. } \\
\text { (1992), Vallance } \\
\text { et al. (1995), } \\
\text { Siebert et al. } \\
\text { (in press) }\end{array}$ & $\begin{array}{l}\text { Vallance et al. } \\
\text { (1995), Kitamura and } \\
\text { Matías (1995), Siebert } \\
\text { et al. (in press) }\end{array}$ & $\begin{array}{l}\text { Siebert et al. } \\
\text { (in press) }\end{array}$ & $\begin{array}{l}\text { Siebert et al. } \\
(1995)\end{array}$ & $\begin{array}{l}\text { Yoshimoto } \\
\text { and Ui } \\
(1997)\end{array}$ \\
\hline Date & - & $30 \mathrm{ka} \mathrm{BP}$ & $23 \mathrm{ka} \mathrm{BP}$ & $\begin{array}{l}\text { Late Pleistocene } \\
\text { (at least } \\
\text { two events) }\end{array}$ & $\begin{array}{l}3100 \mathrm{BP} \\
(1380 \mathrm{cal} \mathrm{BC})\end{array}$ & $1200 \mathrm{BP}$ & $\begin{array}{l}\text { Between } 1555 \text { and } \\
595 \mathrm{BP}\end{array}$ & - & $410 \pm 110 \mathrm{BP}$ & $310 \mathrm{BP}$ \\
\hline $\begin{array}{l}\text { Dormancy period } \\
\text { (years, partially } \\
\text { based on Simkin } \\
\text { and Siebert, 1994) }\end{array}$ & - & $?$ & - & - & $\sim 400$ & $?$ & - & - & - & 590 \\
\hline $\begin{array}{l}\text { Duration and number } \\
\text { of events }\end{array}$ & - & - & - & - & $\begin{array}{l}\text { Numerous } \\
\text { layers, but two } \\
\text { are the most } \\
\text { conspicuous }\end{array}$ & - & - & - & $\begin{array}{l}\text { Unsorted } \\
\text { tephra layer }\end{array}$ & - \\
\hline Thickness range (m) & - & - & $7-0$ & - & $3.2-0.5$ & $0.25-0.10$ & $1.5-0.12$ & - & $>1-0.10$ & - \\
\hline $\begin{array}{l}\text { Maximum extension } \\
(\mathrm{km})\end{array}$ & - & - & $>10$ & - & 8 & 7.5 & 10 & - & $\sim 9.5$ & - \\
\hline Devastated area $\left(\mathrm{km}^{2}\right)$ & - & - & & - & $\sim 55$ & 40 & $30-50$ & - & $\sim 16$ & - \\
\hline Distribution & - & - & Lateral & - & $\begin{array}{l}\text { Lateral } \\
\left(\sim 120^{\circ}\right)\end{array}$ & Lateral $\left(110^{\circ}\right)$ & Lateral $\left(90^{\circ}\right)$ & - & Lateral $\left(40^{\circ}\right)$ & - \\
\hline Composition & - & Andesite & - & - & Andesite & - & Basalt & - & Andesite & - \\
\hline Juvenile clast (\%) & - & - & - & - & Enriched & - & Enriched & - & Poorly 8\% & - \\
\hline Volume $\left(\mathrm{km}^{3}\right)$ & - & - & - & - & - & - & - & - & 0.03 & - \\
\hline Velocity $\left(\mathrm{m} \mathrm{s}^{-1}\right)$ & - & - & - & - & - & - & - & - & - & - \\
\hline $\begin{array}{l}\text { Eruption type } \\
\text { and comments }\end{array}$ & - & $\begin{array}{l}\text { Lateral blast } \\
\text { related to } \\
\text { sector } \\
\text { collapse }\end{array}$ & $\begin{array}{l}\text { Lateral blast } \\
\text { related to } \\
\text { sector } \\
\text { collapse }\end{array}$ & $\begin{array}{l}\text { Lateral blast } \\
\text { (dome blast) } \\
\text { related and } \\
\text { not to sector } \\
\text { collapse }\end{array}$ & $\begin{array}{l}\text { Sector collapse } \\
\text { and exposed } \\
\text { a crytodome }\end{array}$ & $\begin{array}{l}\text { Surges resemble } \\
\text { those of } \\
\text { Mt. St. Helens }\end{array}$ & $\begin{array}{l}\text { Sudden disruption } \\
\text { and decompression } \\
\text { of hot hydrothermal } \\
\text { system with } \\
\text { subsequent magmatic } \\
\text { eruption }\end{array}$ & $\begin{array}{l}\text { Lateral blast } \\
\text { similar to that } \\
\text { Mt. St. Helens } \\
\text { in } 1980\end{array}$ & $\begin{array}{l}\text { Lateral blast } \\
\text { similar to that } \\
\text { Mt. St. Helens } \\
\text { in } 1980\end{array}$ & $\begin{array}{l}\text { Lateral blast } \\
\text { related to } \\
\text { sector } \\
\text { collapse }\end{array}$ \\
\hline Median grain size & - & - & - & - & - & - & - & - & - & - \\
\hline Sorting & - & - & - & - & - & - & - & - & - & - \\
\hline \multirow{3}{*}{$\begin{aligned} \text { Layers (Fisher } & \mathrm{A}_{3} \\
\text { et al., 1987) } & \mathrm{A}_{2} \\
& \mathrm{~A}^{\circ}-\mathrm{A}_{1}\end{aligned}$} & - & - & - & - & - & - & - & - & $\mathrm{x}$ & - \\
\hline & - & - & $\mathrm{x}$ & - & - & - & - & - & $\mathrm{x}$ & - \\
\hline & - & - & - & - & - & - & - & - & - & - \\
\hline
\end{tabular}


indicative of rapid settling where particles do not have time to organize themselves into a densely packed configuration. Branches are aligned in the direction of the flow suggesting late-stage laminar shearing of a dense sediment dispersion (cf. Druitt, 1992). The reverse-to-normal grading observed locally, commonly caused in sediment gravity flows, is a common feature of suspensions deposited under high concentration, rapidly waning flow conditions (Lowe, 1982).

\subsection{The FLAU}

The depositional mechanism of this deposit is believed to have been mostly surge-like in the lower part and dominantly muddy rain fallout in the upper part of the deposit. The lower coarser ash layer pinches out and thins more rapidly on the dune crests and is thicker in the troughs. Accretionary lapilli and vesicular tuff are common in the terminal phase. Most of the fine ash unit was deposited in small smooth channels, with wavelengths of $0.6-1.6 \mathrm{~m}$. These depressions are not erosional because they differ from normal erosional channels by their profile shapes and by the absence of reworked material in the channel. Most likely, therefore, these channels formed by surge-like dune deposits, at the top part of LU-3. The FLAU, a terminal explosive deposit, has a typical phreatomagmatic signature: high degree of fragmentation, good bedding, vesicular tuff and cohesive ash, accretionary lapilli and rare desiccation cracks.

Between Pueblo Nuevo and the lowest crater, both small and large impact craters were filled only by a thin coarse tephra deposit that mantles the crater rim morphology, as suggested by the photographs (Fig. $6 f)$. Thus, the fine ash was clearly deposited after the LU and must be later than the strong ballistic-rainy eruption, and earlier in part than the block and ash flow events, corresponding to an ash cloud surge and fall deposit.

\subsection{The block and ash flow deposits}

Melson and Sáenz $(1968,1973)$ commented that most block and ash flow deposits were produced during the July 31 explosion principally along Río and Quebrada Tabacón, where many trees were uprooted and transported pointing away from the lowest crater. In the most distal and lateral parts of the block and ash flows, turbulent-like movement features in the grass were present, and covered by a centimeter to decimeter thick coarse ash and lapilli deposit (Sáenz, 1977), suggesting an associated pyroclastic surge event. In fact, photographs taken on July 30 and 31 (La Nación newspaper) showed that pyroclastic flows were formed at the same time where a large expanding ash cloud column rose above the vent. Additionally, the stratigraphic position of the block and ash flow deposits above the LU and separated by the FLAU or by a thin reworked deposit (Fig. 9) evidences that it represents the latest strong explosive phase, after a short period of calm. A relatively fine-grained, cross-laminated basal layer deposit and an upper similar layer from ash clouds (ash cloud surges) above moving pyroclastic (cf. Sparks and Walker, 1973; Fisher, 1979) in the block and ash flow deposits, is a common feature of this facies.

According to previous studies, no dome was present on Arenal at this time. The chemical similarity (Melson and Sáenz, 1968, 1973) of the gray andesite of the LU and the juvenile products of subsequent block and ash flows require that this rock represents identical juvenile magmatic material and that the textural dissimilarity reflects a difference in pressure and temperature histories prior and during eruption. In fact, the juvenile component of the block and ash flows is poorly vesiculated, suggesting that it was produced by quenching of the top of the magma column, forming a solidified plug (cryptodome?). This could have occurred when a dramatic decrease in discharge rate (e.g., first hours on July 30 ), caused the pressure in the upper part of magma column to drop below the hydrostatic pressure in the surrounding aquifer. This could have caused influx of water into the shallow magmatic column, generating large explosions and pyroclastic surge and flow events.

\subsection{The role of the structural context and groundwater}

Arenal is cut by several active faults $(<4000$ years old) that disturbed the Holocene tephra sequence in $\mathrm{N}-$ $\mathrm{S}, \mathrm{NE}-\mathrm{SW}$ and NE-SW trends. Another important structure on the western and southern flanks (now covered by lava flows) was interpreted as a caldera rim (Melson and Sáenz, 1968; Sáenz, 1977) or simply as an erosive border at the front of the previous lava field (Borgia et al., 1988). However, in a review of the pre1970 aerial photographs, it is possible to interpret this rim as a reverse fault produced by the continuous propagation of the movements through the cone from the N-S dextral-normal Danta fault, following the structural models of Lagmay et al. (2000). All of the craters are parallel to an $\mathrm{E}-\mathrm{W}$ maximum horizontal compressive stress direction (Lopez, 1999), favoring a radial fracture on the western flank of the volcano. The craters $\mathrm{B}$ and $\mathrm{C}$ probably originated after the lowest one. Thus, the cryptodome could intrude first through the 
shallow-angle thrust fault and after in the shallow radial dike, favoring the lateral blast eruption. The earthquake swarms previous to the eruption may mark the position of a shallow magma front. A quiescent interval of a couple hours before the climatic eruption could be interpreted as if the magma in the pipe had temporally fallen or became stationary.

Melson and Sáenz (1973) suggested that the explosions resulted from degassing of the uppermost part of the magma column oversaturated with volatiles, or alternatively by the rising magma heating up groundwater in the permeable edifice of the volcano. Anderson (1979) reported microprobe analyses of glass inclusions in the mineral phases of one lapillus from the 1968 blast and estimated the water content of the melt to be in the approximately $7 \mathrm{wt} \%$. Reagan et al. (1987) proposed that the mineral assemblages (amphibole) in the andesite grew during the pre-explosive phase under high $\mathrm{pH}_{2} \mathrm{O}$ (4 wt. $\% \mathrm{H}_{2} \mathrm{O}$ ). The morphology and the wide range in vesicularity (2-50 vol.\%, summary in Fig. 12) of juvenile clasts at Arenal, among the presence of moderate vesicular breadcrusted blocks $(<21$ vol.\%), together with strongly vesiculated lapilli and bombs
(>57 vol.\%) in the LU are ambiguous in this respect (magmatic or phreatomagmatic eruption). Similar to Mt. St. Helens, the range of vesicularity of juvenile clasts is compatible with cryptodome growth beneath the west flank. However, some magma/water interactions were present at the moment of the generation of the FLAU, as suggested by the presence of accretionary lapilli and muddy fine ash.

After the eruption, during a short period of seismic observations from August 26 to September 29, 1968, the volcano-tectonic earthquakes were located toward the SE part of Chato volcano, near the Danta fault, with hypocenters between 2 and $8 \mathrm{~km}$ depth (Minakami et al., 1969; Minakami, 1974). Thus, when the conduit was widened, the magma front likely retreated to a depth about $2-8 \mathrm{~km}$.

\section{Comparison with known cases}

Gorshkov (1963) introduced the term "volcanic blast" for describing destructive, laterally directed explosive events that are distinct from vertical eruption columns. Two distinctive characteristics are important in

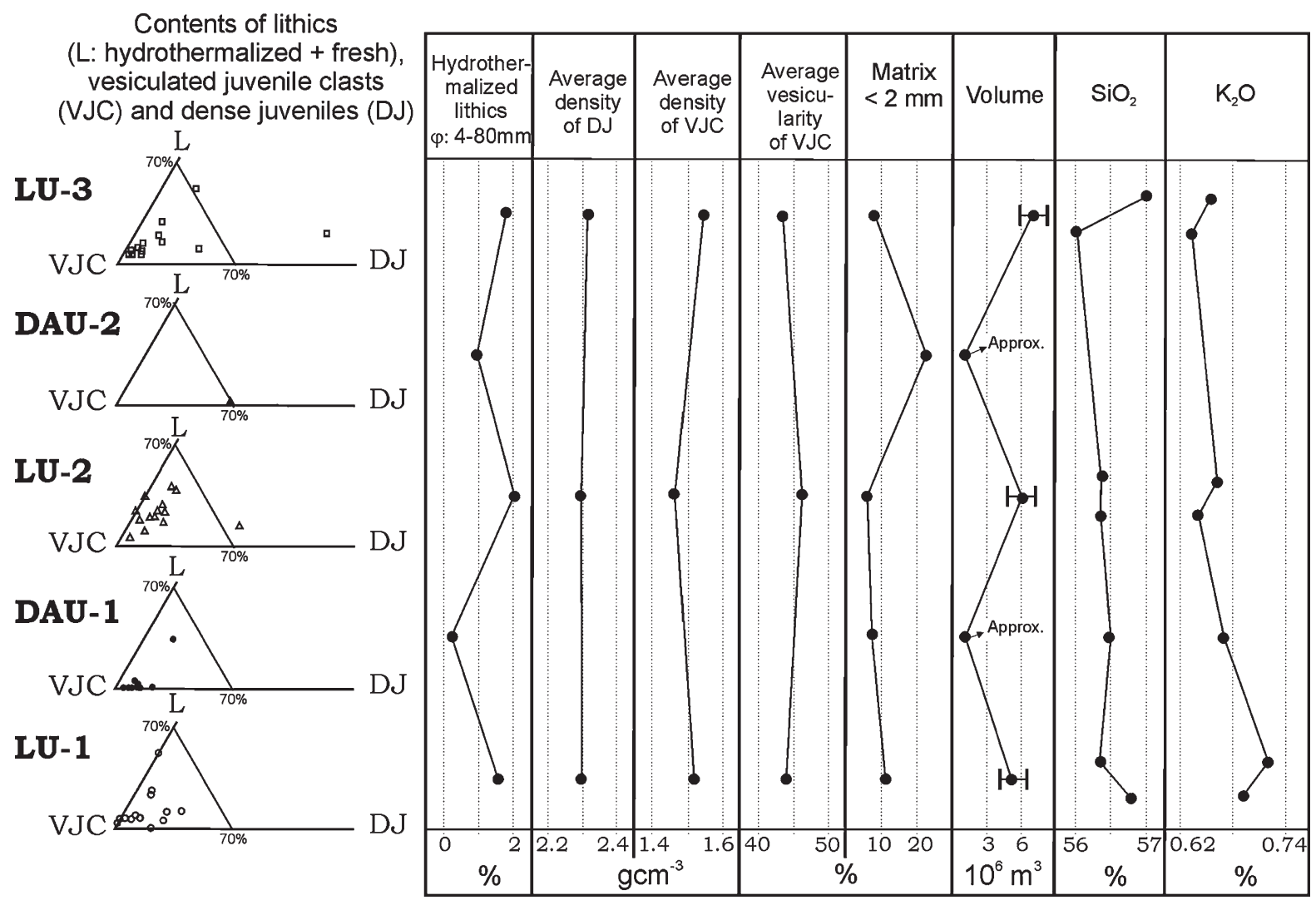

Fig. 12. Summary of main characteristics of the five most important units of Arenal 1968 deposits and their components. 
the conceptual model of directed blast events: (1) horizontal or near-horizontal ejection angles and (2) lack of a strong channeling by topography (Gorshkov, 1963). Blast events are characterized by an enormous destructive power, whose initial modeled velocities are between 223 and $435 \mathrm{~m} \mathrm{~s}^{-1}$ (Wohletz, 1998).

The Arenal deposits from the first day are stratigraphically and compositionally, very similar to the four Mt. St. Helens blast units (cf. Fisher et al., 1987) and other historical blast deposits (Tables 6 and 7): a basal shear layer $\left(B L=A_{0}\right)$, immediately followed by a normally and/or reverse graded, fines-poor layer lapilli $\left(\mathrm{LU}=\mathrm{A}_{1}\right)$, a stratified and cross-stratified fine lapilli-ash unit, and an airfall ash and fine lapilli (FLAU $=\mathrm{A}_{2}$ and $A_{3}$, respectively).

Almost all the well-known blast surge deposits are historical cases (Tables 6 and 8), and at least the case of the 1902 Mt. Pelée eruption is still today a matter of debate concerning its origin and interpretation (see a summary of discussions in Smith and Roobol, 1990). The May 18, 1980 Mt. St. Helens prototype blast eruption and deposit have been studied in detail.
However, many aspects of their formation are still under discussion (see comments in Druitt, 1992; Belousov, 1996). Our example at Arenal is not the exception. Boudon et al. (1994) and Villemant and Boudon (1997) claim for a fallout origin in the case of the LU. Although the LU resemble fall deposits (including ballistic), several lines of evidence (sedimentary structures, variation of facies, eyewitness accounts) support a lateral component (Alvarado et al., 1997, 2004; Schmincke, 2004; this paper). Blast surge deposits generally show only limited thicknesses $(<1-$ $2 \mathrm{~m}$ ) and a limited number of beds owing to the short duration of the eruption that produces them (i.e., Rosi, 1996; Wohletz, 1998). However, the case of Arenal is a special one, in which there does not only exist a combination of processes from lateral blast to ballistic/ fallout, but also the formation of three new craters, which generated a roughly multilayered pyroclastic deposit and contributed to an increase in thickness several times in the proximal and medium facies. Thus, the 1968 Arenal deposits are similar in many respects to those produced by directed blasts at several volcanoes

Table 8

Comparison between the sedimentological characteristics of blast deposits of Mt. St. Helens (Fisher et al., 1987; Druitt, 1992) and Arenal (this work)

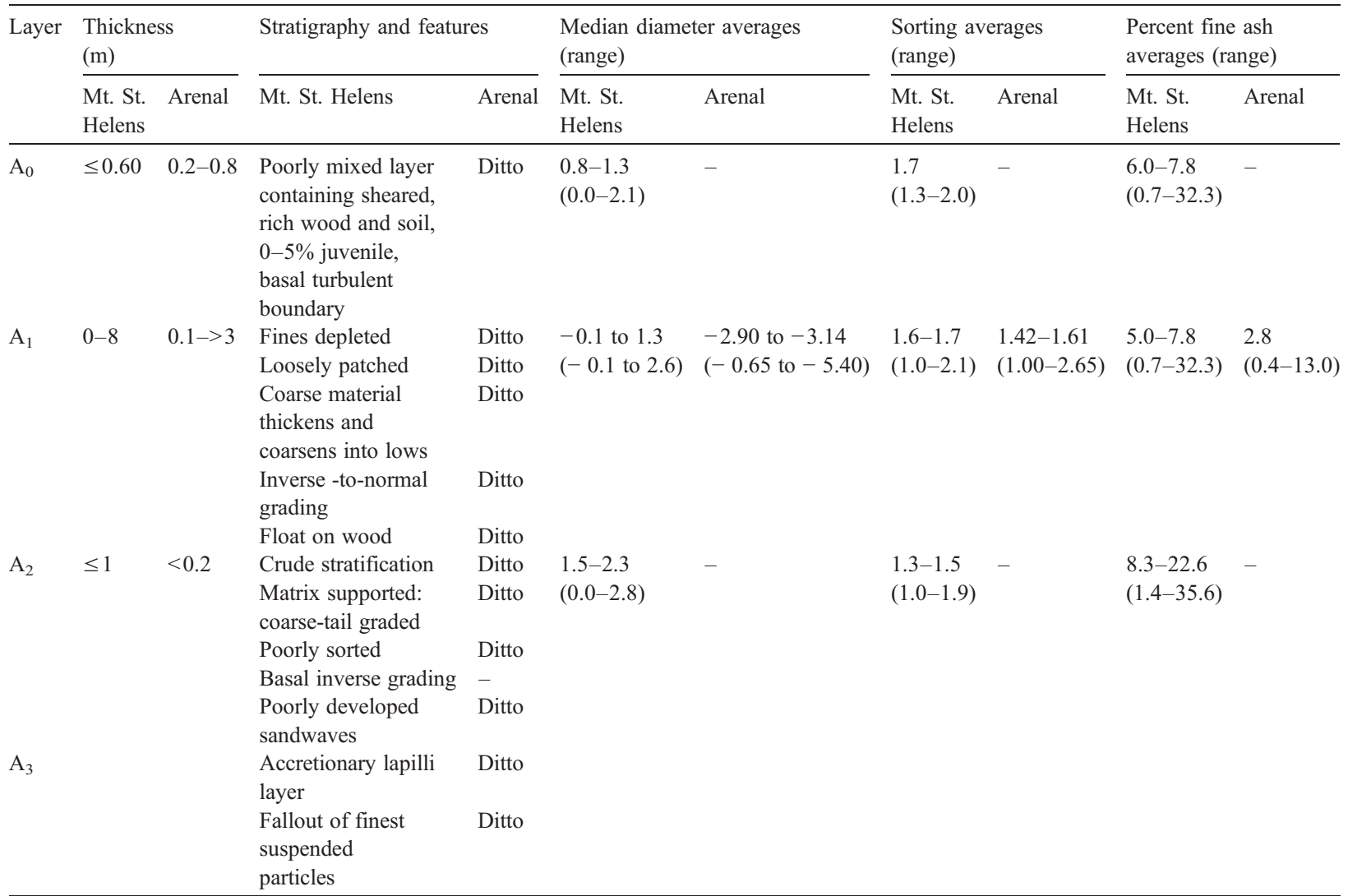


(Table 6). All 10 selected deposits exhibit features associated with surge deposits and similar granulometric features, and have low aspect ratios. One conspicuous characteristic is the presence of coarse-grained beds, ranging from ash to bombs (usually centimeterdecimeter), as is the case of Augustine (Siebert et al., 1995), Soufrière (Boudon et al., 1989), Mt. St. Helens (Druitt, 1992) and Arenal (present work).

With exception of Mt. Pelée and Shiveluch, the rest of the sequences, occurred at volcanoes that had been in repose for hundreds to thousands of years, whose blasts were driven by high-viscosity andesite to dacite magmas (Table 6). Also, most of the eruptions began after a swarm of earthquakes, and especially related to intermediate magnitude $(5.0<\mathrm{Mw}<6.0)$ and shallow depth $(<5 \mathrm{~km})$ earthquakes (Shiveluch Mw 5.2, Arenal Mw 5.1, Pinatubo Mw 5.6, Mt. St. Helens Mw 5.4 and Bezymianny Mw 5.3). In the last two cases, there were trends towards larger earthquakes as stresses built up towards an eruption (Tokarev, 1971; Endo et al., 1981; Zobin, 2001).

Slope failure during emplacement of a cryptodome appears to be the most favorable mechanism for triggering the abrupt explosion of both the cryptodome and its associated hydrothermal system (e.g., Soufrière in Guadeloupe, Bezymianny and Mt. St. Helens), in which the magmatic directed blast immediately followed collapse, with the direction influenced by dip of the detachment (Belousov et al., 2004). At Mt. St. Helens, the directed blast was preceded by failure of the edifice and these events produced different deposits, namely debris avalanche and directed blast deposits, which are composed of different materials and have different volumes, thickness and distribution. At Bezymianny, failure did not precede the blast and the whole mass of debris from the old edifice was outburst only by blast, resulting in a directed blast of "agglomerate and sand facies", which have characteristics of both the debris avalanche and the blast deposits similar to Mt. St. Helens (Bogoyavlenskaya et al., 1985). At Shiveluch, directed-blast deposits are represented only by the directed-blast "agglomerate", while the directed-blast sand facies, or blast proper, seen at Mt. St. Helens is absent (Bogoyavlenskaya et al., 1985).

On the other hand, the Mt Pelée, Mt. Lamington and Arenal blasts were not associated with slope failure, indicating that external depressurization (unloading) is not a prerequisite for blast formation. The majority of prehistoric blast deposits in Ecuador also appear unrelated to slope failure and volcanic debris avalanche formation (Inemin-Geotermica Italiana, 1994; Rosi,
1996). Because lateral blasts often occur in the early stages of dome intrusion, they are frequently followed by a series of less energetic pyroclastic flows (e.g., Mt. Pelée, Bezimianny, Mt. Lamington, Arenal). Although their chemical compositions vary from andesite to dacite, dense and vesicular clast types exist in all, and the ratio of juvenile/accidental lithics, although variable, is high in most of the cases. Two exceptions are the Agustine prehistoric blast deposit and the historical Bandai eruption, which are poor to non-juvenile component content $(0 \%$ to $8 \%$, respectively). There are also several differences in the number of events, durations, devastation and distribution area, mechanism of initial eruption and source mechanism of formation of the blast surges (Tables 6 and 7).

Lateral blasts on the scale of Mt. St. Helens (Kieffer, 1981; Fisher et al., 1987) have to date been documented in association with avalanches only at Bezymianny (Gorshkov, 1959; Belousov, 1996), and possibly at Taunshits volcano in Kamchatka (Melekestsev et al., 1990), Guagua Pichincha volcano in Ecuador (Barberi et al., 1992) and Popocatépetl in Mexico (Siebe et al., 1995). Smaller directed blasts have been described at Lassen Peak (Eppler, 1987; Eppler and Malin, 1989), Soufrière (Boudon et al., 1989), Mt. Pelée (Fisher and Heiken, 1982; Smith and Roobol, 1990), Mt. Lamington (Taylor, 1958), Shiveluch (Bogoyavlenskaya et al., 1985), Pinatubo (Hoblitt et al., 1996), Augustine (Siebert et al., 1995), Cerro Quemado (Conway et al., 1992), Pacaya (Kitamura and Matías, 1995; Vallance et al., 1995), Komagatake (Yoshimoto and Ui, 1997), Arenal (this paper), Soufrière Hill (Druitt and Kookelaar, 2002) and possibly Bandai (Glicken and Nakamura, 1988), Ixhuatán (Siebert et al., in press). They all appear to be cases of a small volume, low-runout $(<20 \mathrm{~km}$ of distance from the crater) and small devastated area $\left(<50 \mathrm{~km}^{2}\right)$ compared with the rest of huge historical blasts (runout of $\sim 30 \mathrm{~km}$ ) and devastated areas of several hundreds of square kilometers.

Blast eruptions are relatively common volcanic events (at least 10 between 1888 and 1997: almost one every decade, see Table 6). Because of their great danger, the correct identification of any blast deposits in the stratigraphic record of Holocene volcanoes is absolutely crucial, especially when it is taken into account that the number of victims caused by blasts in the last century was about 31,000 persons (Rosi, 1996). Surprisingly, only a dozen of prehistoric blast deposit are recognized or described in the literature and many are poorly described (Table 7). The main reason could be the difficulty of recognizing blast deposits from fallout, pumice-rich to lithic-rich pyroclastic density 
currents, or even reworked tephras, in addition that they are easily eroded.

\section{Conclusions}

The shallow intrusion of a bulbous mass of andesitic magma (cryptodome?), possibly through a $\mathrm{N}-\mathrm{S}$ Holocene thrust fault and then as an E-W dike, in a closed conduit, triggered a magmatic eruption, forming the craters $\mathrm{A}, \mathrm{B}$ and $\mathrm{C}$, which were generated along a radial fracture on the western flank of Arenal volcano. The initial vent-clearing phase occurred by sudden decompression of highly pressurized magma $\left(4-7\right.$ wt. $\left.\% \mathrm{H}_{2} \mathrm{O}\right)$ producing high-speed ballistic (initial velocities up to $410 \mathrm{~m} \mathrm{~s}^{-1}$ ) fragments, and a series of directed blasts on July 29,1968 , followed in the next two days, by block and ash flows. The effective temperature of the gaspyroclastic mixture $\left(\sim 300-500{ }^{\circ} \mathrm{C}\right)$ of the blasts was lower than the temperature necessary to char standing woods during the time interval of exposure. Only after deposition could the deposits char wood in some places because of the more prolonged exposure and additional heating on account of the high temperature (600$800^{\circ} \mathrm{C}$ ) of inner parts of large juvenile fragments. Based on these aspects and on the stratigraphy and sedimentological features, the sequence and style of the eruption are very similar to lateral blast explosions triggered by flank collapse of stratovolcanoes (i.e., Mt. St. Helens and Bezymianny), or by radially expanding deposits in all directions (i.e., Mt. Pinatubo).

From the 20 or more recognized prehistoric and historic blast deposits in the world, approximately half were produced by sector collapse of the volcano and the other half by sudden decompression of cryptodomes or lava-dome collapses. The recent blast deposits have an apparent recurrence of one event/decade. The adequate recognition of the blast facies as described here present not only an additional case of blast deposit, but can help in the understanding of other historic and prehistoric cases, and their related hazards, especially in the case of small volume stratocones in convergent margins. Therefore, when studying old deposits, it is important to pay attention to the base of the block and ash flow sequences, where coarse-grained, relatively thin (decimeter- to meter-thick) layers with diffuse crossstratification, open-work texture, relative fine-poor matrix, and usually reverse grading, may reveal the presence of a blast deposit, simulating together less hazardous normal fallouts removed elsewhere by erosion. Their recognition in the cone-building lithofacies is important for the hazard evaluation, especially for those dormant andesitic/dacitic volcanoes.

\section{Acknowledgements}

We thank Instituto Costarricense de Electricidad (ICE) for financing exploratory holes, laboratory and logistic support, and Francisco (Chico) Arias and Luis A. Madrigal for field and lab assistance during this project. Parts of the figures were drawn by Wendy Pérez and Jeisson Chaves. Field work on Arenal (H-US and MS) was financed by Deutscher Akademischer Austauschdienst (DAAD) and the cost for digging the trenches by a Leibniz grant from the Deutsche Forschungsgeinshaft (DFG). The geochemical analyses were performed in the Department of Geological Sciences, Rutgers University. Detailed comments of W. Hildreth, C.J.N. Wilson and T. Druitt quite improved the paper. Finally, we thank W.M. Melson and an anonymous reviewer for their constructive comments.

\section{References}

Alvarado, G.E., Soto, G.J., 2002. Pyroclastic flow generated by craterwall collapse and outpouring of the lava pool of Arenal volcano, Costa Rica. Bull. Volcanol. 63, 557-568.

Alvarado, G.E., Schmincke, H.-U., Soto, G.J., Sumita, M., 1997. The 1968 basaltic andesite eruption at Arenal volcano (Costa Rica): fallout, surge or pyroclastic flow? IAVCEI, Puerto Vallarta, Mexico, General Assembly, Abstracts, p. 82.

Alvarado, G.E., Schmincke, H.-U., Soto, G.J., Bolge, L.L., Sumita, M., 2004. La erupción tipo blast de 1968, volcán Arenal, Costa Rica. V Congreso Geológico Nacional, San José, Costa Rica, Programas y Resúmenes, pp. 25-26.

Anderson, A.T., 1979. Water in some hyperstenic magmas. J. Geol. 87, 509-531.

Barberi, F., Ghigliotti, M., Macedonio, G., Orellana, H., Pareschi, M.T., Rosi, M., 1992. Volcanic hazard assessment of Guagua Pichincha (Ecuador) based on past behavior and numerical models. J. Volcanol. Geotherm. Res. 49, 53-68.

Barquero, R., Alvarado, G.E., Matumoto, T., 1992. Arenal volcano (Costa Rica) premonitory seismicity. In: Gasparini, P., Scarpa, R., Aki, K. (Eds.), Volcanic Seismology. IAVCEI Proceedings in Volcanology, vol. 3. Springer, Berlin, pp. 84-96.

Belousovf, A., 1996. Deposits of the 30 March 1956 directed blast at Bezymianny volcano, Kamchatka, Russia. Bull. Volcanol. 57, 649-662.

Belousov, A., Voight, B., Belousova, M., 2004. To blast or not blast? That is the question. Electronic Abstract, IAVCEI General Assembly, Pucón, Chile.

Bolt, B.A., Horn, W.L., Macdonald, G.A., Scott, R.F., 1975. Geological Hazards. Earthquakes-Tsunamis-Volcanoes-Avalanches-Landslides-Floods, 2nd edition. Springer, New York, pp. 1-228.

Bogoyavlenskaya, G.E., Braitseval, O.A., Melekstsev, I.V., Kiriyanov, V.Y., Miller, C.D., 1985. Catastrophic eruptions of the directedblast type at Mount St. Helens, Bezymianny and Shiveluch volcanoes. J. Geodyn. 3, 189-218.

Borgia, A., Poore, C., Carr, M.J., Melson, W.G., Alvarado, G.E., 1988. Structural, stratigraphic and petrologic aspects of the Arenal-Chato 
volcanic system, Costa Rica: evolution of a young stratovolcanic complex. Bull. Volcanol. 50, 86-105.

Boudon, G., Dagain, J., Semet, M.P., Westercamp, D., 1987. Notice explicative de la Carte Géologique a 1/20000 du Massive Volcanique de la Soufrière (Departement de la Guadeloupe, Petites Antilles). Bur. Rech. Geól. Min. 1-43.

Boudon, G., Semet, M.P., Vincent, P.M., 1989. The evolution of La Grande Découverte (La Soufrière) volcano, Guadeloupe (F.W.I.). In: Latter, J.L. (Ed.), Volcanic Hazards. Assessment and Monitoring. Springer, Berlin, pp. 86-109.

Boudon, G., Rançon, J.P., Traineau, H., Kieffer, G., 1994. Violent reactivation of a dormant volcano: the 1968 explosive eruption of Arenal volcano, Costa Rica. International Volcanology Congress (IAVCEI), Ankara, Turkey, September 12-16, 1994 (Abstract).

Boudon, G., Rançon, J.P., Kieffer, G., Traineau, H., 1996. L'éruption de 1968 du volcan Arenal (Costa Rica): un exemple de réactivation violente d'un volcan en sommeil. Volcanisme actif de L'Amérique Centrale et du Mexique. Bull. Sect. Volcanol., Soc. Géol. Fr. 39, 9.

Chaves, R., Sáenz, R., 1970. Efectos de las erupciones recientes del volcán Arenal, Costa Rica. Inf. Semest. Enero-Junio, Inst. Geogr. Nac., San José 17-24.

Conway, F.M., Vallance, J.W., Rose, W.I., Johns, G.W., Paniagua, S., 1992. Cerro Quemado, Guatemala: the volcanic history and hazards of an exogenous volcanic dome complex. J. Volcanol. Geotherm. Res. 52, 303-323.

Druitt, T.H., 1992. Emplacement of the 18 May 1980 lateral blast deposit ENE of Mount St. Helens, Washington. Bull. Volcanol. 54, 554-572.

Druitt, T.H., Kookelaar, B.P., 2002. The eruption of Soufrière Hills volcano, Montserrat, from 1995 to 1999. Geol. Soc. Lond. Mem. 21, 1-645.

Endo, E.T., Malone, S.D., Noson, L.L., Weaver, C.S., 1981. Location, magnitudes, and statistics of the March 20-May 18 earthquake sequence. In: Lipman, P.W., Mullineaux, D.R. (Eds.), The 1980 Eruption of Mount St. Helens, Washington. U.S. Geol. Surv. Prof. Paper, vol. 1250, pp. 93-107.

Eppler, D.B., 1987. The May 1915 Eruption of Lassen Peak: II. May 22 volcanic blast effects, sedimentology and stratigraphy of deposits, and characteristics of the blast cloud. J. Volcanol. Geotherm. Res. 31, 65-85.

Eppler, D.B., Malin, M.C., 1989. The May 1915 eruptions of Lassen Peak, California: I. Characteristics of events occurring on 19 May. In: Latter, J.L. (Ed.), Volcanic Hazards. Assessment and Monitoring. Springer, Berlin, pp. 180-200.

Feigenson, M.D., Carr, M.J., 1985. Determination of major, trace and rare earth elements in rocks by DCP-AES. Chem. Geol. 51, $19-27$.

Feigenson, M.D., Bolge, L.L., Carr, M.J., Herzberg, C.T., 2003. REE inverse modeling of HSDP2 basalt: evidence for multiple sources in the Hawaiian plume. Geochem. Geophys. Geosyst. 4 (2), 8706. doi:10.1029/2001GC00271.

Fisher, R.V., 1979. Models for pyroclastic surges and pyroclastic flows. J. Volcanol. Geotherm. Res. 6, 305-318.

Fisher, R.V., 1990. Transport and deposition of a pyroclastic surge across an area of high relief: the 18 May 1980 eruption of Mount St. Helens, Washington. Geol. Soc. Amer. Bull. 102, $1038-1054$.

Fisher, R.V., Heiken, G., 1982. Mt. Pelée, Martinique: May 8 and 20, 1902, pyroclastic flows and surges. J. Volcanol. Geotherm. Res. 13, 339-371.

Fisher, R.V., Schmincke, H.-U., 1984. Pyroclastic Rocks. Springer, Berlin, pp. 1-472.
Fisher, R.V., Glicken, H.X., Hoblitt, R.P., 1987. May 18, 1980, Mount St. Helens deposits in South Coldwater Creek, Washington. J. Geophys. Res. 92, 10267-10283.

Fudali, R.F., Melson, W.G., 1972. Ejecta velocities, magma chamber pressure and kinetic energy associated with the 1968 eruption of Arenal volcano. Bull. Volcanol. 35, 383-401.

Glicken, H., Nakamura, Y., 1988. Restudy of the 1988 eruption of Bandai volcano, Japan. Proceedings of the Kagoshima International Conference on Volcanoes, Abstracts, p. 64.

Gorshkov, G.S., 1959. Gigantic eruption of the volcano Bezymianny. Bull. Volcanol. 20, 77-109.

Gorshkov, G.S., 1963. Directed volcanic blasts. Bull. Volcanol. 26, 83-88.

Hoblitt, R.P., Wolfe, H.E., Scott, W.E., Couchman, M.R., Pallister, J.S., Javier, D., 1996. The preclimatic eruptions of Mount Pinatubo, June 1991. In: Newhall, C.G., Punongbayan, R.S (Eds.), Fire and Mud: Eruptions and Lahars of Mount Pinatubo. Univ. Washington Press, Seattle. http://pubs.usgs.gov/pinatubo/ hoblitt2/indesx.html.

Inemin-Geotermica Italiana, 1994. Mitigación del Riesgo Volcánico en el Área Metropolitana de Quito. Síntesis Actualizada. Instituto Geográfico Nacional, pp. 1-78 + annexes.

Kieffer, S.W., 1981. Fluid dynamics of the May 18 blast at Mount St. Helens. In: Lipman, P.W., Mullineaux, D.R. (Eds.), The 1980 eruptions of Mount St. Helens, Washington. U.S. Geol. Surv. Prof. Pap., vol. 1250, pp. 379-400.

Kitamura, S., Matías, O., 1995. Tephra stratigraphic approach to the eruptive history of Pacaya volcano, Guatemala. Sci. Rep. Tohoku Univ., 7th Series (Geography) 45, 1-41.

Lagmay, A.M.F., van Wyk de Vries, B., Kerle, N., Pyle, D.M., 2000 Volcano instability induced by strike-slip faulting. Bull. Volcanol. 62, 331-346.

Lirer, L., Vinci, A., 1991. Grain-size distribution of pyroclastic deposits. Sedimentology 38, 1075-1083.

Lopez, A., 1999. Neo- and paleostress partitioning in the SW corner of the Caribbean plate and its fault reactivation potential. $\mathrm{PhD}$ thesis, Tübingen Geowissenchaftliche Arbeiten 53, 1-294.

Lorenz, V., 1974. Vesiculated tuffs and associated features. Sedimentology 21, 273-291.

Lowe, D.R., 1982. Sediment gravity flow: II. Depositional models with special reference to the deposits of high density turbidity currents. J. Sediment. Petrol. 52, 279-297.

Matumoto, T., 1976. Prediction of a volcanic eruption implied from seismic data. Rev. Geogr. Inst. Panam. Geogr. Hist. 5, 285-293.

Melekestsev, I.V., Braiseva, O.A., Ponomareva, V.V., Sulerzhitsky, L.D., 1990. Ages and dynamics of development of active volcanoes of Kurile-Kamchatka region. Int. Geol. Rev. 32, 436-448.

Melekestsev, I.V., Litasova, S.N., Sulerzhiskiy, L.D., 1992. The age and scale of catastrophic eruptions of the directed explosion type in the Avacha volcano (Kamchtaka) in the Late Pleistocene. Volcanol. Seismol. 13, 135-146.

Melson, W.G., Sáenz, R., 1968. The 1968 eruption of Volcán Arenal: preliminary summary of field and laboratory studies. Smithsonian Center for Short-Lived Phenomena, Report 7/1968, pp. 1-35.

Melson, W.G., Sáenz, R., 1973. Volume, energy and cyclicity of eruptions of Arenal volcano, Costa Rica. Bull. Volcanol. 37, 416-437.

Minakami, T., 1974. Prediction of volcanic eruptions. In: Civetta, L., Gasparini, P., Luongo, G., Rapolla, A. (Eds.), Physical Volcanology. Elsevier Sci. Publ. Co., pp. 313-333. Elsevier, Amsterdam.

Minakami, T., Utibori, S., Hiraga, S., 1969. The 1968 eruption of volcano Arenal, Costa Rica. Bull. Earthq. Res. Inst. 47, 783-802. 
Molina, J.R., 2003. In: Molina González, J.R. (Ed.), El volcán Arenal: el coloso de San Carlos, pp. 1-197.

Reagan, M.K., Gill, J.B., Malavassi, E., Garcia, M.O., 1987. Changes in magma compositions at Arenal volcano, Costa Rica: 19681985: realtime monitoring of open-system differentiation. Bull. Volcanol. 49, 415-434.

Rosi, M., 1996. Quantitative reconstruction of recent volcanic activity: a contribution to forecasting of future eruptions. In: Scarpa, R., Tilling, R.I. (Eds.), Monitoring and Mitigation of Volcano Hazards. Springer, Berlin, pp. 631-674.

Sáenz, R., 1977. Erupción del volcán Arenal en el año 1968. Rev. Geogr. Am. Cent. 5-6, 149-188.

Schmincke, H.-U., 2004. Volcanism. Springer, pp. 1-324.

Siebe, C., Abrams, M., Macías, J.L., 1995. Derrumbes gigantes, depósitos de avalancha de escombros y edad del actual cono del volcán Popocatépetl. Volcán Popocatépetl: estudios realizados durante la crisis de 1994-1995. Centro Nacional de Prevención de Desastres, Universidad Nacional Autónoma de México D.F., pp. 195-220.

Siebert, L., Begét, J.E., Glicken, H., 1995. The 1883 and lateprehistoric eruptions of Augustine volcano, Alaska. J. Volcanol. Geotherm. Res. 66, 367-395.

Siebert, L., Alvarado, G.E., Vallance, J.W., in press. Large-volume volcanic edifice failures in Central America and associated hazards. In: Rose, W.I., Bluth, G., Carr, M.J., Ewert, J., Patino, L., Vallance, J. (Eds.), Volcanic Hazards in Central America. Spec. Paper 412, Geol. Soc. Amer.

Sigurdsson, H., Houghton, B., McNutt, S.R., Stix, J. (Eds.), 2000. Encyclopedia of Volcanoes. Academic Press, pp. 1-1417.

Simkin, T., Siebert, L., 1994. Volcanoes of the World. Geoscience Press, Smithsonian Inst., Tucson, pp. 1-349.

Simkin, T., Siebert, L., 2000. Earth's volcanoes and eruptions: an overview. In: Sigurdsson, H., Houghton, B., McNutt, S.R., Stix, J. (Eds.), Encyclopedia of Volcanoes. Academic Press, pp. 249-261.

Smith, A.L., Roobol, M.J., 1990. Mt. Pelée, Martinique; a study of an active island-arc volcano. Mem. Geol. Soc. Amer. 175, 1-105.
Sparks, R.S.J., Walker, G.P.L., 1973. The ground surge deposit: a third type of pyroclastic rock. J. Volcanol. Geotherm. Res. 3, 1-37.

Sparks, R.S.J., Wright, J.V., 1979. Welded air-fall tuffs. In: Chapin, C.E., Elston, W.E. (Eds.), Ash-Flow Tuffs. Spec. Pap.-Geol. Soc. Am., vol. 180, pp. 155-166.

Steinberg, G.S., Lorenz, V., 1983. External ballistic of volcanic explosions. Bull. Volcanol. 46, 333-348.

Taylor, G.M.A., 1958. The 1951 eruption of Mount Lamington, Papua. Bur. Min. Resour. Geol. Geophys. Bull., Canberra 38, 1-117.

Tokarev, P.I., 1971. Forecasting volcanic eruptions from seismic data. Bull. Volcanol. 35, 243-250.

Vallance, J.W., Siebert, L., Rose Jr., W.I., Girón, J.R., Banks, N.G., 1995. Edifice collapse and related hazards in Guatemala. In: Ida, Y., Voight, B. (Eds.), Models of Magmatic Processes and Volcanic Eruptions. J. Volcanol. Geotherm. Res., vol. 66, pp. 337-355.

Valentine, G.A., Fisher, R.V., 2000. Pyroclastic surges and blasts. In: Sigurdsson, H., Houghton, B., McNutt, S.R., Stix, J. (Eds.), Encyclopedia of Volcanoes. Academic Press, pp. 571-580.

Villemant, B., Boudon, G., 1997. The 1968 explosive eruption of Arenal volcano, Costa Rica: stratigraphy, vesicularity and geochemistry of the products. IAVCEI, Puerto Vallarta, Mexico, General Assembly, Abstracts, p. 156.

Walker, G.P.L., 1971. Grainsize characteristics of pyroclastic deposits. J. Geol. 79, 696-714.

Williams, H., McBirney, A.R., 1979. Volcanology. Freeman, Cooper \& Co, San Francisco, pp. 1-397.

Wohletz, K.H., 1998. Pyroclastic surges and compressible two-phase flow. In: Freundt, A., Rosi, M. (Eds.), From Magma to Tephra. Modelling Physical Processes of Explosive Volcanic Eruptions. Elsevier, Amsterdam, pp. 247-311.

Yoshimoto, M., Ui, T., 1997. 1640 eruption of Hokkaido Komagatake volcano, Japan. Puerto Vallarta, México, International Association of Volcanology and Chemistry of the Earth's Interior, General Assembly, Abstracts, p. 133.

Zobin, V.M., 2001. Seismic hazard of volcanic activity. J. Volcanol. Geotherm. Res. 112, 1-14. 